UNIVERSIDADE DE SÃO PAULO

FACULDAdE DE FILOSOFIA CIÊNCIAS E LETRAS DE RIBEIRÃo PRETO

DEPARTAMENTO DE PSICOLOGIA

PRogRAMA DE Pós GRAdUAÇÃo EM PSICOBIOLOGIA

Mariana dos Santos Moretto

Efeitos da Interação de Estímulos Acústicos e Visuais na Estimação Subjetiva de Tempo de Indivíduos Treinados e não Treinados em Dança 

UNIVERSIDADE DE SÃO PAULO

FACULDAdE DE FILOSOFIA CIÊNCIAS E LETRAS DE RIBEIRÃo PRETO

DEPARTAMENTO DE PSICOLOGIA

Programa DE Pós GraduAÇÃo EM PSICOBIOLOGIA

\title{
Efeitos da Interação de Estímulos Acústicos e Visuais na Estimação Subjetiva de Tempo de Indivíduos Treinados e não Treinados em Dança
}

\author{
Mariana dos Santos Moretto
}

Dissertação apresentada à Faculdade de Filosofia, Ciências e Letras de Ribeirão Preto da Universidade de São Paulo, como parte das exigências para a obtenção do título de Mestre em Ciências, Área: Psicobiologia.

RIBEIRÃO PRETO - SP 



\section{Efeitos da Interação de Estímulos Acústicos e Visuais na Estimação Subjetiva de Tempo de Indivíduos Treinados e não Treinados em Dança}

Dissertação apresentada à Faculdade de Filosofia, Ciências e Letras de Ribeirão Preto da Universidade de São Paulo, como parte das exigências para a obtenção do título de Mestre em Ciências.

Área de concentração: Psicobiologia.

Orientador: Prof. Dr. José Lino de Oliveira Bueno

Colaborador: Prof. Dr. Francisco Carlos Nather

RIBEIRÃO PRETO - SP 


\section{FICHA CATALOGRÁFICA}

Moretto, Mariana dos Santos

Efeitos da interação de estímulos acústicos e visuais na estimação subjetiva de tempo de indivíduos treinados e não treinados em dança, 2011.

97 p.: il.; $30 \mathrm{~cm}$

Dissertação de Mestrado, apresentada à Faculdade de Filosofia, Ciências e Letras de Ribeirão Preto/USP. Área de concentração: Psicobiologia.

Orientador: Bueno, José Lino Oliveira.

1. Tempo Subjetivo. 2. Balé. 3. Imagens estáticas. 3. Movimento. 4. Interação música imagem. 


\section{Efeitos da Interação de Estímulos Acústicos e Visuais na Estimação Subjetiva de Tempo de Indivíduos Treinados e não Treinados em Dança.}

Dissertação apresentada à Faculdade de Filosofia, Ciências e Letras de Ribeirão Preto da Universidade de São Paulo, como parte das exigências para a obtenção do título de Mestre em Ciências.

Área de concentração: Psicobiologia.

Data da aprovação:

Banca Examinadora

Prof. Dr:

Instituição:

Assinatura:

Prof. Dr:

Instituição:

Assinatura:

Prof. Dr:

Instituição:

Assinatura: 
DEDICO meu trabalho

Aos meus pais, Maria Alice e Evair, que sempre estão ao meu lado e contribuem com amor, segurança e muitas lições de sabedoria;

Ao meu noivo Carlos, pela paciência e serenidade que me passa em todos os momentos;

Ao meu Irmão Felipe, por compreender uma irmã tão "estressada". 


\section{AGRADECIMENTOS}

Ao Departamento de Psicologia e Educação da Faculdade de Filosofia Ciências e Letras de Ribeirão Preto da Universidade de São Paulo;

Ao Prof. Dr. José Lino de Oliveira Bueno pela orientação, apoio e oportunidade de desenvolver esta pesquisa;

Ao Prof. Dr. Francisco Carlos Nather pelas críticas e sugestões imprescindíveis à realização desta pesquisa;

Ao químico e técnico do laboratório "Processos Associativos, Controle Temporal e Memória” João Luis Segala Borin pelo apoio técnico;

Aos colegas do laboratório, em especial à Dra. Danielle Judice-Daher pelo auxílio nas análises estatísticas e ao Prof. Dr. Érico Firmino pelos ajustes técnicos dos estímulos acústicos;

À Profa. Helle Nice Raile Riccardi, que me fez persistir na arte da Dança;

À Diretora e professora de Balé Clássico Luciana Junqueira que tanto contribuiu para minha profissionalização na Dança e permitiu que seus bailarinos participassem desta pesquisa;

À Profa. Silvana Helena Conti que autorizou a participação de seus bailarinos na pesquisa;

A todas as pessoas que gentilmente participaram dos experimentos;

A todos que direta e indiretamente contribuíram para a realização deste trabalho. 
MORETTO, M. S. Efeitos da interação de estímulos acústicos e visuais na estimação subjetiva de tempo de indivíduos treinados e não treinados em dança. 2011. 97 p. Dissertação (Mestrado) - Faculdade de Filosofia Ciências e Letras de Ribeirão Preto, Universidade de São Paulo, Ribeirão Preto, 2011.

\section{Resumo}

Estudos sobre a estimação subjetiva de tempo, sob a abordagem da Nova Estética Experimental, utilizam obras de arte (músicas, esculturas e pinturas) como estímulos, buscando revelar quais os processos psicológicos envolvidos na apreciação artística. Alguns desses estudos mostraram que a percepção de movimento de corpos humanos em posições de balé influencia a estimação subjetiva de tempo e que há um efeito do treinamento em artes dos participantes nestas estimações. Outros estudos que utilizaram estímulos acústicos (músicas clássicas de complexidades distintas) também revelaram que a estimação subjetiva de tempo pode estar relacionada com as características das composições. Alguns estudos que abordam a interação som/imagem indicam um domínio do estímulo acústico sobre o visual em tarefas que requerem percepção temporal. O presente estudo propõe a utilização de estímulos acústicos e visuais, com o objetivo de verificar se trechos musicais de diferentes andamentos (rápido e lento) e imagens estáticas com distintas representações de movimento, conjuntamente, afetam a percepção subjetiva de tempo de indivíduos treinados e não treinados em Balé Clássico. No primeiro experimento participaram 58 indivíduos não treinados em dança, e no segundo experimento participaram 49 indivíduos treinados em dança, todos com idade entre 18 e 38 anos de ambos os sexos, os quais foram submetidos a sequiências randômicas de estímulos compostos por um trecho de música clássica e uma imagem de posição de balé clássico. A tarefa dos participantes foi reproduzir o tempo de apresentação dos estímulos sob o paradigma prospectivo. Para controle experimental foram feitos dois grupos: Grupo Controle Imagem (GCI) com 32 participantes e um Grupo Controle Música (GCM) com 25 participantes. A análise dos resultados indica que tanto para bailarinos, como para pessoas não treinadas em dança, o movimento representado nas imagens exerce um efeito nas estimações temporais dos participantes, que pode ser mais ou menos evidenciado dependendo do tipo de andamento musical com o qual é apresentado simultaneamente. Para pessoas não treinadas em dança, a música em andamento lento (Adágio) exerceu um efeito sobre as estimações das imagens que foram estimadas com a mesma duração do tempo real, enquanto que para os indivíduos treinados em dança, foi a música em andamento rápido (Allegro) que exerceu tal efeito. Estes efeitos distintos do andamento musical nas estimações das imagens podem estar relacionados com o treinamento dos participantes, em função da congruência entre o movimento representado nos estímulos e visuais e o andamento musical do estímulo acústico.

Palavras-chave: Tempo subjetivo, balé, imagens estáticas, movimento, interação música imagem. 
MORETTO, M. S. Effects of interaction of acoustic and visual stimuli in the subjective time estimation of individuals trained and not trained in dance. 2011. 97p. Dissertation (Master degree) - University of Philosophy, Sciences and Letters of Ribeirao Preto, University of Sao Paulo, Ribeirao Preto, 2011.

\begin{abstract}
Subjective Time studies, under the approach of the New Experimental Aesthetics, has been using works of art (music, sculptures and paintings) as stimuli, which seek to reveal the psychological processes involved in artistic appreciation. Some of these studies showed that the perception of motion of human bodies in positions of Ballet influences the subjective estimation of time and that there is an effect of the training in arts by the participants in these estimations. Other studies that used acoustic stimuli (classical music of different complexities) also revealed that the subjective estimation of time may be related to the characteristics of the compositions. Some studies on the interaction sound / image indicate a domination of an acoustic stimulus on the visual tasks which require time perception. This study proposes the use of acoustic and visual stimuli, in order to verify pieces of music of different tempos (fast and slow) and still images with different representations of motion, together, affect the subjective perception of time by trained individuals and not trained in Classical Ballet. In the first experiment involving 58 individuals not trained in dance and in the second experiment involved 49 individuals trained in dance, all aged between 18 and 38 years of both sexes, who were subjected to random sequences of stimuli consisting of a piece of music and an image of classical ballet position. The participants' task was to reproduce the time of presentation of stimuli under the prospective paradigm. For experimental control groups were made, a Picture Control Group (ICG) with 32 participants and a Music Control Group (GCM) with 25 participants. The results indicate that both dancers and for people not trained in dance, the movement represented in the images has an effect on participants' time estimations that may be more or less evident depending on the tempo of the music with which it is presented simultaneously. For people not trained in dance the slow music tempo (Adagio) has an effect on the estimations of the images that were estimated with the same length of real time, while those trained in dance, the acoustic stimulus that exerted such influence over the estimates of the temporal images was the music in fast tempo (Allegro). These distinct effects of the tempo of the music in the estimations of the images may be related to the training of participants, depending on the congruence between movement and visual stimuli represented in the tempo of the music and the acoustic stimulus.
\end{abstract}

Keywords: Time subjective, ballet, static images, motion, interaction music image. 


\section{SUMÁRIO}

INTRODUÇÃ

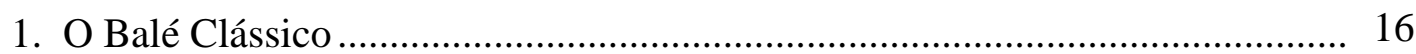

1. 1. Edgar Degas e o Balé Clássico.............................................................. 20

2. A representação de movimento em obras de arte.......................................... 23

3. O estudo de Tempo Subjetivo ................................................................ 32

3.1. Tempo Subjetivo e a Estética Experimental ............................................... 35

4. A interação de estímulos acústicos e visuais.............................................. 41

5. Objetivos e Justificativas................................................................. 45

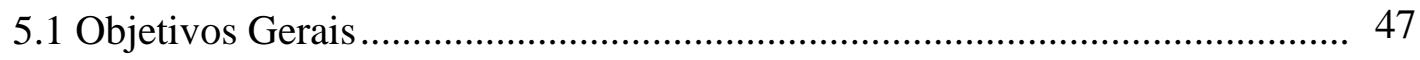

EXPERIMENTOS

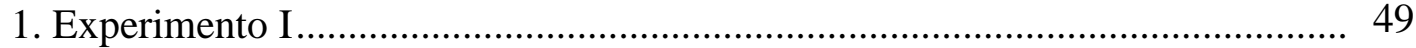

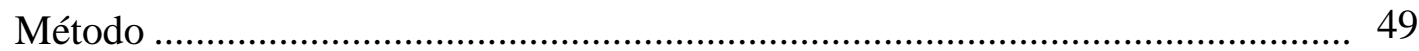

Resultados .............................................................................................. 54

Discussão............................................................................................ 59

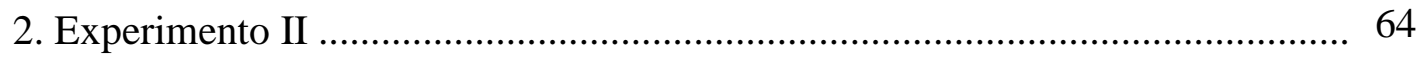

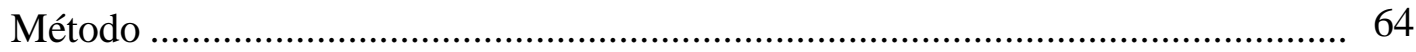

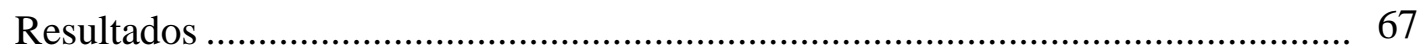

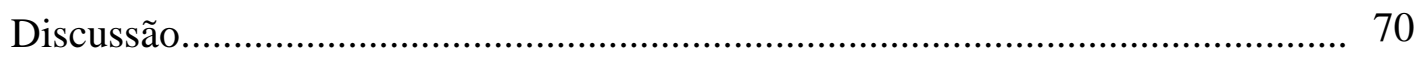

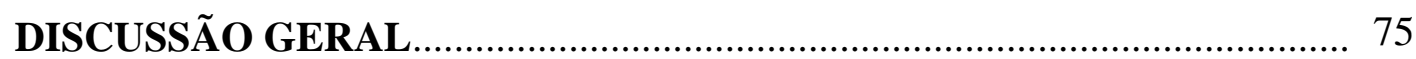

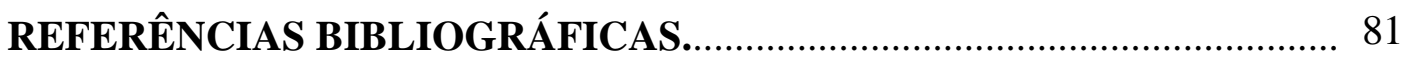

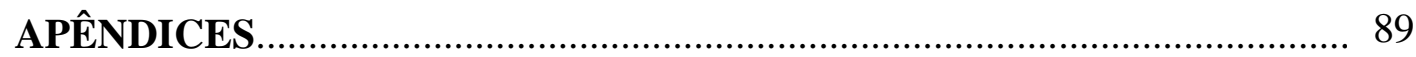

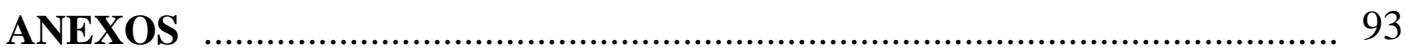




\section{Introdução}

O tempo é algo inerente à trajetória humana. A nossa rotina, os planos que fazemos e as ações que executamos são possíveis porque consideramos o fator temporal. Dependendo das situações que vivenciamos sentimos o tempo passar de diferentes maneiras. É comum ouvirmos expressões do tipo "o que é bom dura pouco", esta expressão revela como a experiência temporal é dependente do que vivenciamos ou fazemos. Situações de prazer podem fazer com que a experiência temporal seja encurtada, ao contrário, situações de extrema tensão ou angústia podem prolongar a experiência temporal. Vários estudos buscam desvendar os processos cognitivos subjacentes a estimação subjetiva de tempo, a memória e a atenção constituem alguns destes processos. A literatura de tempo subjetivo fornece uma série de procedimentos que possibilitam o estudo da percepção temporal em ambientes experimentais. Estas pesquisas têm revelado que as condições contextuais são determinantes na experiência temporal.

A abordagem psicobiológica da Estética Experimental possibilita o uso de obras de arte em pesquisas de tempo subjetivo. A análise das propriedades colativas das obras como, por exemplo, se são complexas ou simples, inéditas ou familiares, assim como a escolha da abordagem que será utilizada na pesquisa (sintética ou genuína) permitem o controle experimental necessário para verificar qual das variáveis exerce influência na estimação temporal. Este rigor científico permite inferir sobre os processos subjacentes à estimação subjetiva de tempo quando os indivíduos participam de uma apreciação estética. Pesquisas nesta área utilizaram como estímulos músicas clássicas e imagens de esculturas e pinturas separadamente e revelaram que a complexidade musical e a intensidade de representação de movimento em imagens estáticas são características que afetam a estimação subjetiva de tempo. Neste contexto, destacam-se trabalhos que utilizaram as obras do artista impressionista Edgar Degas (1834 - 1917). O empenho deste artista em estudar formas de representação de movimento de corpos humanos é revelado em suas pinturas e esculturas, as quais, em grande parte, retrataram o tema do Balé Clássico. Os resultados de pesquisas que utilizaram como estímulos suas esculturas e pinturas de bailarinas para verificar seus efeitos nas estimações temporais dos participantes, evidenciaram que as diferentes intensidades de representação de movimento de suas obras exerciam um efeito correlacionado nas estimações temporais. 
Estas pesquisas indicaram ainda um efeito do treinamento em artes dos participantes (músicos, artistas plásticos e bailarinos) nas estimações temporais. Outros trabalhos, neurocientíficos, que pesquisaram o efeito do treinamento na percepção de movimento, também verificaram diferenças nas ativações de áreas cerebrais de indivíduos treinados e não treinados em dança.

A forma como os seres humanos percebem a interação música imagem tem instigado vários pesquisadores. Através de estudos comportamentais e neurofisiológicos tem se verificado que os benefícios sensoriais da integração visual e auditiva são extensos para a percepção de objetos e que o substrato neural destas interações envolve o recrutamento de areais cerebrais previamente pensadas como unimodais. De uma forma sucinta, estes estudos indicam que existe uma sobreposição entre os sistemas auditivo e visual. Ambos são capazes de fornecer informação espacial e temporal e muitas vezes contribuem para uma percepção mais apurada de um determinado objeto. Essa integração audiovisual é fundamental para a apreciação de determinadas formas de expressão artística. Como, por exemplo, uma apresentação de balé clássico exige a percepção musical e visual da obra para que a apreciação estética seja completa.

Considerando os avanços em pesquisas de tempo subjetivo que utilizam obras de arte auditivas e visuais separadamente e as diferenças encontradas nas estimações temporais de indivíduos treinados e não treinados em artes, seria possível a reunião das variáveis: música, artes visuais e movimento de forma a revelar novos aspectos sobre a percepção subjetiva de tempo? A associação destas três variáveis afetaria a estimação subjetiva da mesma forma que interferem isoladamente? Bailarinos profissionais que possuem conhecimento técnico de música, da performance do movimento e da terminologia dos passos característicos do Balé, ao observarem os fatores isoladamente e depois associados apresentariam diferenças nas estimações temporais?

Esta pesquisa verificou o efeito da interação de estímulos acústicos e visuais na estimação subjetiva de tempo de indivíduos treinados e não treinados em dança. Para tanto, foram realizados dois experimentos nos quais participantes treinados e não treinados em dança reproduziram a duração de apresentação de obras de arte acústicas e visuais apresentadas simultaneamente. Cada experimento foi realizado segundo os procedimentos e abordagens da estética experimental e paradigmas metodológicos propostos nas pesquisas de tempo subjetivo. Em todos os experimentos foram utilizadas imagens bidimensionais (fotografias digitalizadas) de esculturas de bailarinas em três diferentes posições corporais, nos grupos experimentais as imagens foram apresentadas 
em conjunto com trechos de música clássica em dois distintos andamentos, um rápido e outro lento. Serão discutidos a seguir, alguns aspectos dos movimentos realizados na dança do Balé Clássico, como a terminologia e procedimentos de execução dos passos que compõem a movimentação deste estilo de dança. As obras de Edgar Degas, pinturas e esculturas de bailarinas, serão discutidas sob o ponto de vista de um bailarino focalizando-se a identificação dos passos representados nas imagens (1). A representação de movimento em imagens estáticas será discutida a partir de trabalhos teóricos que analisaram as formas de representação figurativas do movimento e a partir de trabalhos experimentais que verificaram como seres humanos percebem um movimento, que na verdade, não é real (2). As relações entre a percepção de movimento e tempo subjetivo serão discutidas a partir de trabalhos recentes que revelaram uma correlação positiva entre a intensidade de movimento representado em imagens e a estimação temporal, através de uma abordagem psicobiológica e com embasamento na estética experimental. As implicações do treinamento em diferentes modalidades artísticas nas percepções de movimento e nas estimações temporais também serão discutidas (3). Finalizando, serão ainda discutidos os efeitos da interação de estímulos acústicos e visuais na maneira como os seres humanos percebem tais estímulos e os efeitos desta interação na estimação temporal (4). 


\section{O Balé Clássico}

A prática da dança envolve movimentos corporais que são constituídos por passos específicos. No caso do balé clássico, o movimento é resultado da prática de exercícios, cada exercício de uma aula de balé é composto por uma série de passos com execução e terminologia própria ${ }^{1}$.

De uma forma geral, toda aula de balé é composta por exercícios realizados na Barra $^{2}$ e no Centro da sala de aula. Após o aquecimento corporal, que se constitui basicamente de movimenos de alongamento e ativação muscular, a aula inicia-se na barra que exerce função de apoio. Os exercícios na barra preparam o corpo para os exercícios que serão realizados no Centro (Caminada, 1999). Os exercícios realizados com o apoio da barra são comedidos e conscienciosos, ou seja, desenvolvem-se de forma a trabalhar grupos musculares específicos numa ordenação estável e coordenada (um exemplo de exercício realizado na barra pode ser visto na Figura 2c). Na barra, objetiva-se adequar a postura corporal de forma a definir o equilíbrio e a sustentação do eixo anatômico, trabalhando-se o alongamento, a flexibilidade, o tônus e o fortalecimento muscular (Bertoni, 1992; Bambirra, 1993). Sucintamente, os exercícios realizados na barra são o Battement Tendu (passo caracterizado pelo movimento de batida $^{3}$ esticada dos pés, no qual, o bailarino desliza um dos pés sobre o chão até estendê-lo completamente, tocando o chão com apenas a ponta do pé que estendeu), o Plié (movimento de flexão dos joelhos), o Battement jeté (movimento de batida jogada dos pés, o pé que se desloca é estendido com vigor até que não toque mais o chão), o Rond de Jambe (volta da perna desenhando um círculo no chão) e o Grand Battement (movimento de lançamento de uma das pernas para o ar, passo representado na Figura 2c).

Após o trabalho na barra o bailarino está pronto para iniciar os exercícios de Centro, que constituem a segunda parte de uma aula de balé. O Centro é composto pelos mesmos exercícios realizados na barra, acrescido de movimentos mais dançantes (Studio de Dança Luciana Junqueira, 2001; Bertoni, 1992). Suscintamente, os exercícios realizados no Centro são o Port de Brás (movimento caracterizado pelo

\footnotetext{
${ }^{1}$ Ao longo do texto, muitas vezes, será utilizado o termo passo como sinônimo de movimento.

${ }^{2}$ A barra é uma estrutura de ferro, geralmente afixada ao chão ou à parede, que serve de apoio para o bailarino nas etapas iniciais de uma aula de balé Clássico.
} 
deslocamento dos braços no ar), o Battement Tendu (mesmo exercício realizado previamente na barra, mas no centro, é realizado sem apoio), o Adágio (exercício caracterizado por movimentos lentos e suaves, compostos por passos como developpés 4 e Arabesques ${ }^{5}$ ), o Pirouettes (giro de $360^{\circ}$ que o bailarino realiza centralizando seu eixo de rotação em apenas uma das pernas), o Allegro (exercício composto por movimentos rápidos e precisos, como saltos e giros), o Waltz para grandes saltos (exercício com movimentos grandiosos, como saltos nos quais o bailarino abre as pernas no ar antes de retornar ao chão) e Port de Brás com agradecimento, neste momento final o bailarino agradece ao mestre que ministrou a aula através de movimentos suaves dos braços e do curvamento do tronco em sinal de gratidão (Pavlov, 2000).

A execução dos passos que compõem os exercícios de uma aula de balé é determinada pelo andamento musical. Assim, existem exercícios que são realizados de forma mais ágil e vigorosa e por isso são acompanhados de músicas mais rápidas como aquelas em andamento do tipo Allegro ${ }^{6}$ e outros exercícios são executados de forma mais lenta e suave e são acompanhados por músicas de andamento do tipo Adágio. O exercício Adágio é executado em andamento lento, enquanto o exercício Allegro é executado em andamento rápido.

Os movimentos desenvolvidos em Adágio são realizados em tempo lento, de forma contínua, alongada, com equilíbrio, simetria e precisão. "No Adágio os movimentos se ligam com clareza e harmonia, observando a fluidez da utilização musical, a sutileza dos acentos e a dinâmica da forma musical” (Bertoni, 1992 p. 100). Na música, o Adágio é um andamento vagaroso que varia de 45 a 120 bpm (batidas por minuto). Em contrapartida, o exercício Allegro é vivo e alegre. Seus movimentos são precisos, elásticos e saltitantes com acentos bem definidos. Na música, Allegro é a expressão que indica andamento rápido e varia de 152 a 208 bpm (Bertoni, 1992 e Lacerda,1967). A relação de cada exercício da aula de balé com o seu respectivo andamento musical pode ser consultada no Apêndice I.

\footnotetext{
${ }^{3}$ O termo batida refere-se ao deslocamento das pernas e dos pés da posição inicial, apoiados no chão, para sua completa extensão. Constituí-se, portanto, na saída e no retorno deste deslocamento para a posição inicial do pé que foi extendido.

${ }^{4}$ Developpé: passo caracterizado pelo movimento de estender uma das pernas o mais alto possível em relação ao chão.

5 Arabesque: passo caracterizado pelo movimento de elevação de uma das pernas estendida ao ar num ângulo de até $90^{\circ}$ em relação à perna de base (Figura 1a).

${ }^{6}$ Dentre os exercícios realizados na aula de balé clássico, destacam-se os exercícios de Adágio e Allegro, cuja nomenclatura é a mesma do andamento musical no qual são executados.
} 
De uma forma geral, em todas as etapas da aula, existe uma estrutura de exercícios específicos que vão do mais simples ao mais complexo em relação ao controle corporal, a consciência corporal e rítmica do estudante de balé. Assim, por exemplo, o que se inicia como um Arabesque na aula tornar-se-á um Penché ${ }^{7}$ no centro. A dificuldade e a complexidade dos exercícios vão aumentando conforme o bailarino evolui em sua aprendizagem.

$\mathrm{Na}$ aprendizagem do Balé Clássico existem cinco posições básicas que são ensinadas nos estágios iniciais e servirão de base para a execução de todos os passos. Diferentemente dos conceitos de passo e movimento, a posição refere-se a uma colocação estática necessária para o início de um passo ou para a ligação de um passo com outro em uma coreografia. As posições básicas são: $1^{\mathrm{a}}, 2^{\mathrm{a}}, 3^{\mathrm{a}}, 4^{\mathrm{a}}$ e $5^{\mathrm{a}}$ posições dos pés e dos braços (Bertoni, 1992; Studio de Dança Luciana Junqueira, 2001). Na primeira posição dos braços os membros superiores ficam colocados na frente do corpo, na altura da cintura, formando um círculo com os dedos quase se tocando e as palmas das mãos viradas para o corpo. Na segunda posição, os braços ficam abertos, ligeiramente arredondados, as mãos levemente voltadas para frente e abaixo da linha dos ombros. Na terceira posição um dos braços é conservado em $2^{\mathrm{a}}$ posição e o outro acima da cabeça, ligeiramente à frente dela com a palma da mão virada para a testa. $\mathrm{Na}$ quarta posição um braço fica acima da cabeça, ligeiramente à frente dela com a palma da mão virada para a testa e o outro fica em $2^{\mathrm{a}}$ posição. Finalmente, na quinta posição, os dois braços ficam acima da cabeça com os dedos quase se tocando, e as mãos viradas para a testa.

Existem ainda posições de braços que são aprendidas após o bailarino ter desenvolvido uma postura corporal adequada, relacionadas à correta colocação das cinturas escapular e pélvica. Estas posições são denominadas de posições de braços em Arabesque e segundo a Escola Italiana ${ }^{8}$ (Bertoni, 1992; Pavlov, 2000), são9 :

- Primeiro Arabesque: o braço que está à frente do corpo é o mesmo da perna de base, o outro braço fica ao lado do tronco, um pouco abaixo da linha dos ombros (ver Figura 3g: disposição dos braços);

\footnotetext{
${ }^{7}$ Para a execução do passo Penché a perna é elevada atrás do tronco formando um ângulo de $180^{\circ} \mathrm{em}$ relação à perna de base e procura-se manter um ângulo de $90^{\circ} \mathrm{em}$ relação a perna que se ergue e o tronco do bailarino, ver Figura 3g).

${ }^{8}$ A escola de balé clássico adotada no presente estudo foi a escola Italiana por ser uma das escolas mais tradicionais e difundidas atualmente.

${ }^{9}$ Neste estudo serão descritos as principais posições do corpo que são aprendidas quando o bailarino já possui uma experiência maior em Balé Clássico.
} 
- Segundo Arabesque: o braço que está à frente do corpo do bailarino é oposto ao da perna de base (ver Figura 3e);

- Terceiro Arabesque: ambos os braços ficam à frente do corpo, um acima do ombro e o outro abaixo do ombro, permitindo a visualização do colo, pescoço e face do bailarino.

- Quarto Arabesque: A perna de base será aquela mais distante do observador, enquanto que a outra está alongada para trás, em Arabesque. O braço que fica à frente do corpo é o mesmo da perna que está en l'air e o braço, correspondente à perna de base, está posicionado ao lado;

- Quinto Arabesque: os braços estão colocados em $3^{\mathrm{a}}$ posição de Arabesque, a perna de base fica em demi-plié (meia flexão dos joelhos) e também é a mais próxima do expectador.

As cinco posições dos pés podem ser vistas na Figura 1. A primeira posição é feita colocando os dois pés unidos pelos calcanhares, formando um ângulo de $180^{\circ}$. Na segunda posição mantém-se a configuração inicial, mas os pés são afastados para lados opostos seguindo a distância dos ossos do quadril (ilíacos). A terceira posição é formada colocando-se um dos pés na frente do outro mantendo a configuração en dehors $^{10}$, ou seja, abertos. Na quarta posição mantém-se a configuração da terceira posição, mas os pés são afastados de forma a ficar um mais a frente do que o outro. A quinta posição é feita cruzando-se e unindo-se os dois pés de forma que um fique justaposto ao outro.

O Balé Clássico caracterizou-se como uma das formas de expressão artística mais conhecida no mundo, principalmente na França, país no qual se fundamentou a técnica (Caminada, 1999; Mendes, 2001). A primeira escola de balé clássico foi fundada em Paris, em 1661 com o nome de $L^{\prime}$ Academie Royale de Danse, na qual o mestre Pierre Beauchamps (1650 - 1729) codificou e elaborou a técnica clássica acadêmica, definindo as cinco posições básicas dos pés (Bertoni, 1992; Achcar, 1986).

\footnotetext{
${ }^{10}$ En dehors: palavra francesa que significa para fora, no Balé Clássico corresponde ao movimento de rotação para fora dos músculos internos das cochas resultando na rotação dos pés na mesma direção.
} 


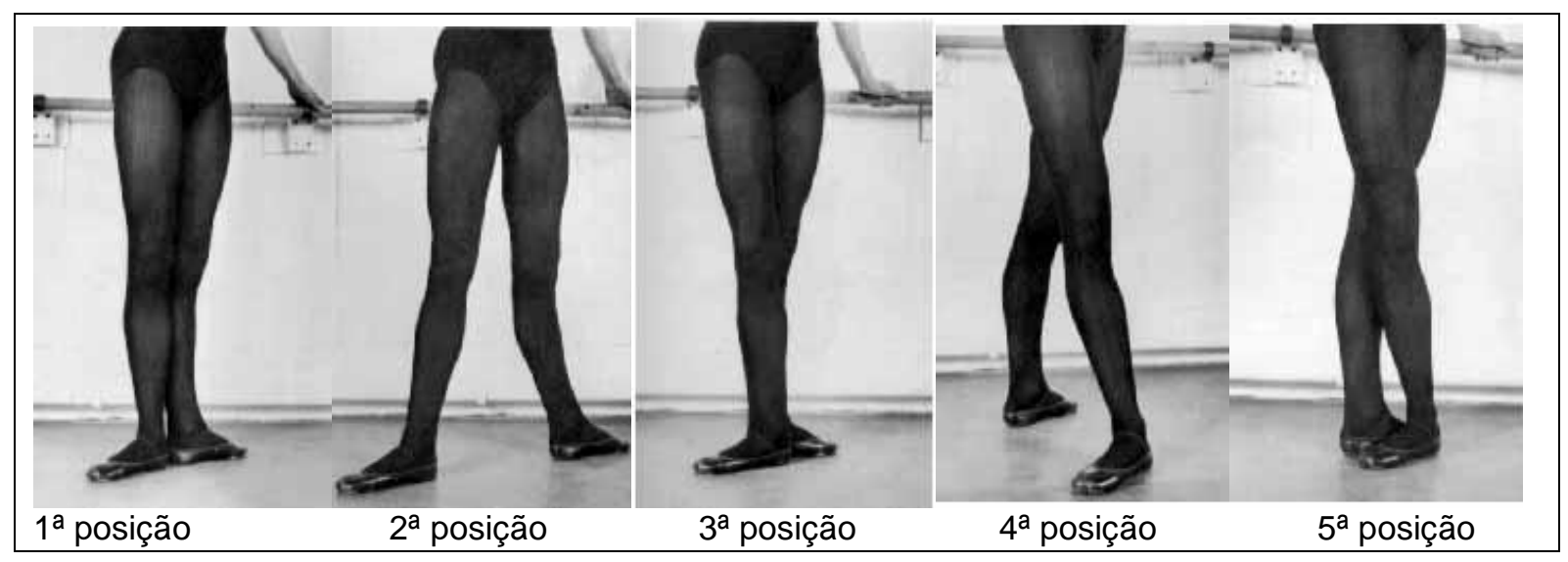

Figura 1: As cinco posições dos pés: definidas pelo francês Pierre Beauchamps, elas descrevem o começo ou o fim obrigatório de todos os passos, além de estarem intermediando as demais marcações. (Fonte: http://balletfefe 7.blogspot.com/2007/07/as-cinco-posies-dos-ps.html).

Dois séculos mais tarde, o artista impressionista francês Edgar Degas, dedicou grande parte de suas produções artísticas à reprodução de bailarinas em diferentes contextos de dança como, por exemplo, se apresentando em um teatro (ver Figura 2a), ensaiando ou mesmo descansando após exaustivo treino (Growe, 2001). Desde então, o Balé Clássico vem sendo retratado de várias formas por diferentes artistas, através de pinturas, esculturas, vídeos e fotografias. Dentre eles, as obras de Degas merecem destaque devido ao grande empenho do artista em retratar peculiaridades do mundo do Balé, que vão desde os trajes usados pelas bailarinas até a qualidade dos movimentos representados em suas pinturas e esculturas.

\section{1. Edgar Degas e o Balé Clássico}

O artista impressionista Edgar Degas (1834-1917) é mundialmente conhecido pela qualidade da representação de movimento de suas obras. As pinturas e esculturas por ele produzidas baseavam-se em temas como mulheres se banhando, cavalos e bailarinas. Suas obras despertaram o interesse de vários estudiosos das artes visuais que se dedicaram à análise de suas obras (Argan, 1995; Growe, 2001; Strickland, 2004). Há aproximadamente uma década, seus trabalhos também vêm sendo utilizados como 
estímulos em pesquisas científicas que abordam a percepção de movimento e tempo subjetivo (Nather, 2006; Nather \& Bueno, 2006a; Nather \& Bueno, 2011a, b).

As pinturas e esculturas de Degas que representam bailarinas são repletas de informações sobre a técnica do Balé Clássico. Os quadros retratam o dia-a-dia dos ensaios, das aulas e das apresentações, revelando características (figurinos, tipo físico das bailarinas e situações de backstage) da prática desta dança no século XIX (Figuras 2 e 3). Os detalhes técnicos representados pelo artista em seus quadros revelam a preocupação em retratar a técnica do balé clássico em suas peculiaridades, o que certamente demandou muito estudo por parte do artista. Por exemplo, a colocação dos pés en dehors das bailarinas em suas pinturas revela um cuidado com a representação fiel da técnica do Balé Clássico porque estes detalhes indicam que a formação técnica da bailarina retratada é apurada (na Figura 2 b e 2 c os pés das bailarinas que estão no chão representam a colocação en dehors dos pés).

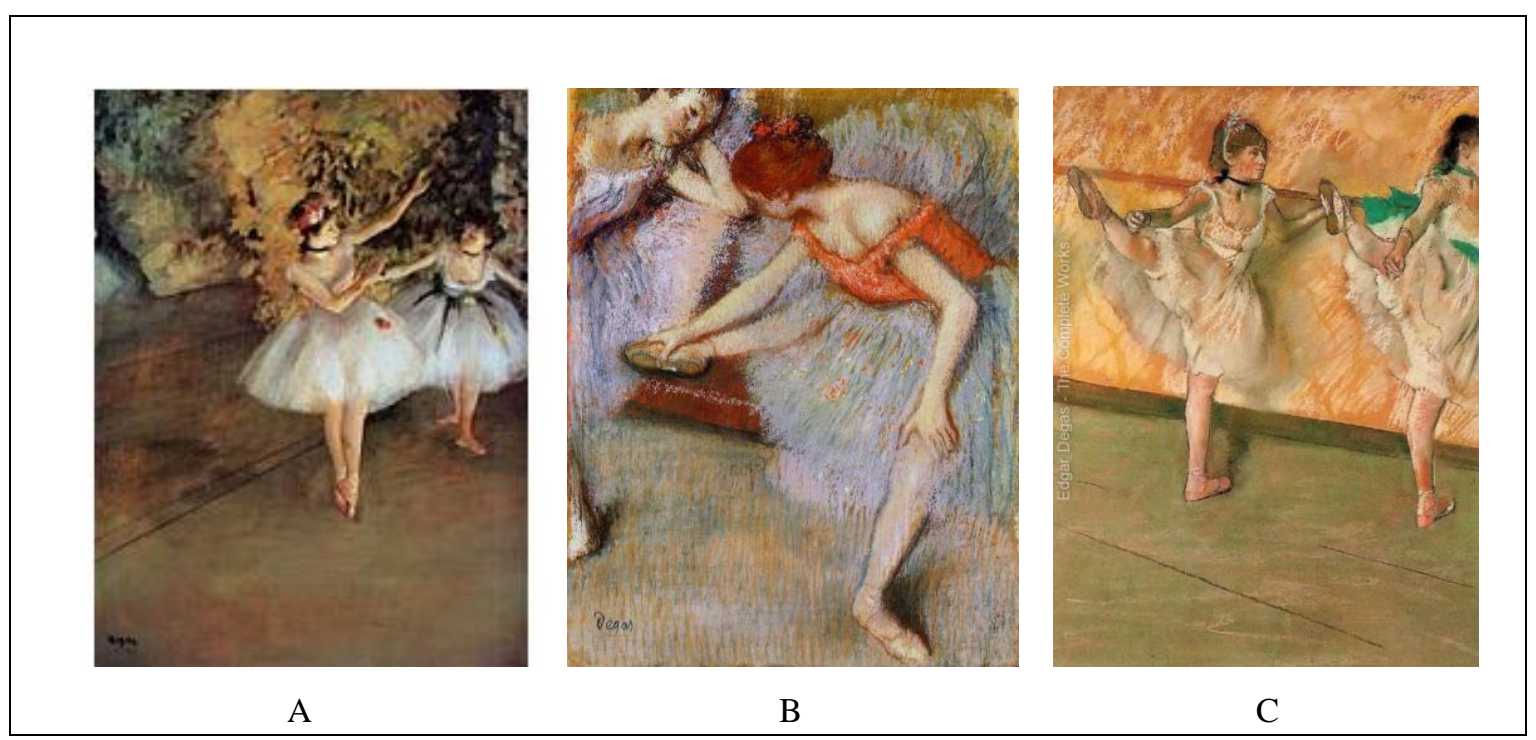

Figura 2. Pinturas originais de Edgar Degas (Fonte: www.edgar-degas.org) A) Two dancers on stage: a bailarina principal realiza o passo courru com port de brás: fragmento de uma coreografia; B) Two dancers on the banch: momento de repouso entre os ensaios. C) Dancers on the bar: retrata o exercício Grand Battement realizado na barra.

As esculturas em bronze possuem contornos precisos que reproduzem a tonicidade muscular necessária para a execução dos passos que representam. Para um bailarino estas obras podem representar mais do que esculturas ou imagens. Elas podem suscitar uma série de conhecimentos relacionados à sua aprendizagem como a 
nomenclatura do passo representado, a sua dificuldade de execução e até mesmo evocar sensações e sentimentos relacionados à sua experiência na dança. As esculturas da Figura 3 retratam desde movimentos livres de repouso (Figura 3a), até movimentos complexos de Arabesques (Figura 3e, f e g).

Grande parte das obras de Edgar Degas pode ser vista no acervo encontrado no Museu de Arte de São Paulo (MASP), o segundo maior acervo do artista no mundo. Algumas dessas obras são mostradas nas Figuras 2 e 3.

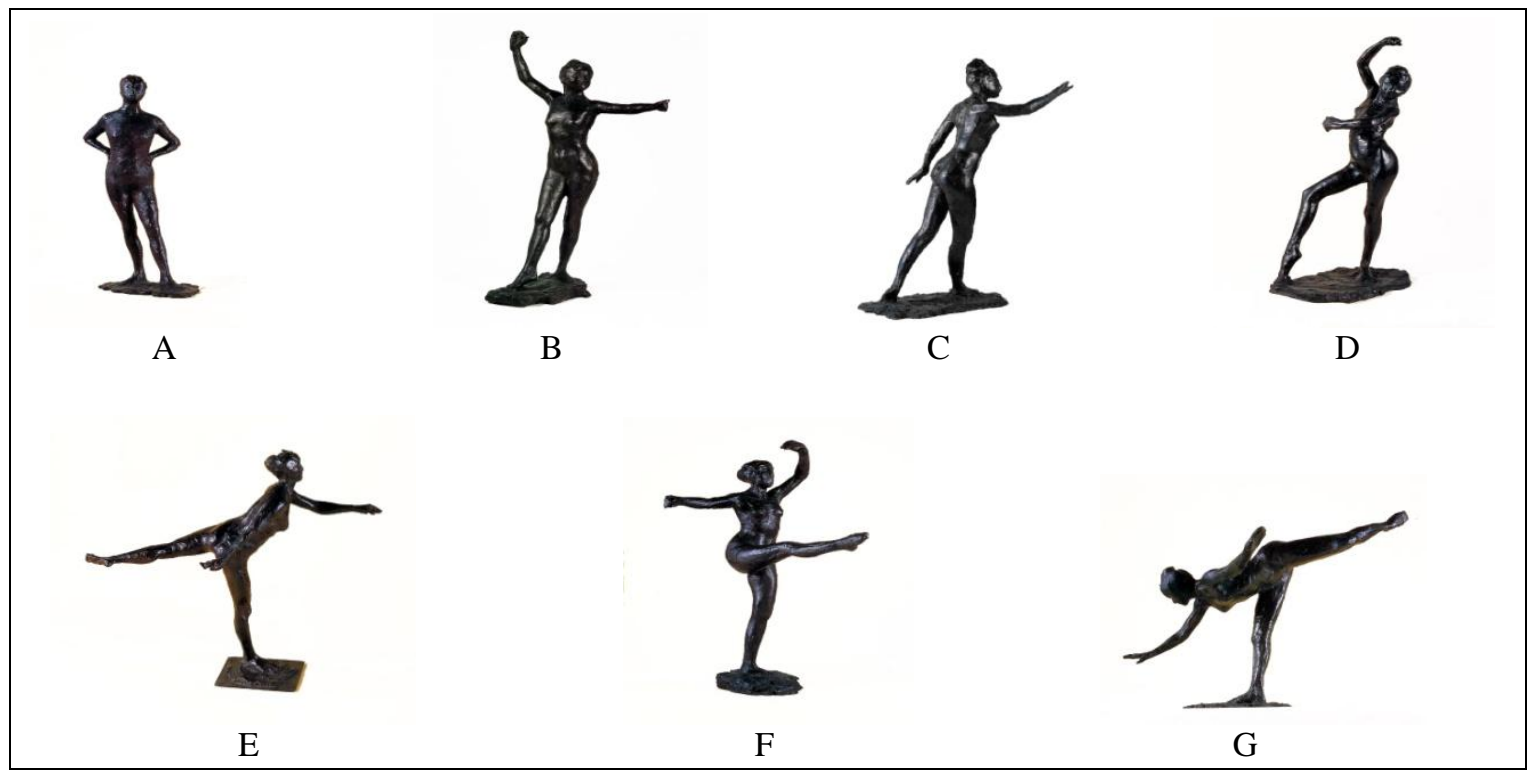

Figura 3. Esculturas de Edgar Degas: títulos retirados do catálogo fotográfico do MASP (Marques, 1999) e imagens utillizadas por Nather e Bueno (2008). A) "Bailarina em repouso": 1.5 - pontos; B) "Prelúdio para dança": 3.5 - pontos; C) "Primeiro tempo do grande Arabesque": 4.0 - pontos; D) "Dança espanhola": 4.5 -pontos; E) "Arabesque sob a perna direita": 5.0 - pontos; F) "Quarta posição à frente sob perna esquerda": 5.0 - pontos e G - "Terceiro tempo do grande Arabesque": 6.0-pontos.

Alguns estudos têm revelado resultados relevantes sobre a percepção de movimento em imagens estáticas. É possível que a representação do Balé Clássico em esculturas e pinturas seja forte o suficiente para evocar no bailarino a mesma sensação de realizar ou observar um movimento real. 


\section{A representação de movimento em obras de arte}

Alguns pesquisadores tem se dedicado a analisar a representação de movimento em obras de arte (Braddick, 1995; Cutting, 2002; Nather \& Bueno, 2006a). Por exemplo, Cutting (2002) analisou o movimento em pinturas, desenhos e fotografias de diferentes períodos históricos. De acordo com o autor, existem cinco formas de representação do movimento. Dentre elas, o "Equilíbrio Dinâmico" explica que a representação de movimento está relacionada à simetria da posição da figura humana em uma obra bidimensional (por exemplo, uma pintura ou a fotografia de uma escultura). A colocação das pernas e quadris em relação aos ombros e braços pode garantir maior ou menor equilíbrio no corpo, gerando mais ou menos movimento representado.

Sendo o movimento oriundo da intersecção espaço-tempo, as diferentes formas de representar ou induzir o movimento em obras de arte visuais podem envolver mais do que técnicas de representação, mas também interações diversas resultantes do encontro entre obra e expectador. Mesmo um objeto estático pode suscitar alguma percepção de movimento porque devido aos constantes movimentos oculares, a imagem percebida deste objeto na retina pode se mover (Nather \& Bueno, 2006a). Dessa forma, ao se observar uma obra de arte o movimento pode ser real, ou seja, o objeto se desloca no espaço tridimensional como, por exemplo, ao assistir uma apresentação de balé onde o bailarino realmente se desloca no palco. Por outro lado, o movimento observado também pode ser oriundo de mecanismos de percepção que se relacionam à visão bidimensional da retina como, por exemplo, ao observar pinturas que representam um movimento estático, neste caso o movimento é aparente.

Mas como utilizar obras de arte e a representação dos passos de Balé Clássico em estudos científicos? A Nova Estética Experimental proposta por Berlyne (1974) consiste numa abordagem que fornece critérios para o estudo científico do comportamento dos indivíduos durante a observação de um episódio estético. Nesta abordagem, há um empenho em se estabelecer ligações entre o fenômeno estético e fenômenos psicológicos assim, as propriedades da obra que será utilizada como estímulo e as questões motivacionais envolvidas são aspectos relevantes para estudos nesta área. Na seleção da obra de arte devem-se considerar suas propriedades colativas ${ }^{11}$

\footnotetext{
${ }^{11}$ Propriedades colativas referem-se ao conjunto de características de uma obra, relacionadas não apenas à obra, mas também ao contexto social no qual está inserida.
} 
como, por exemplo, se ela é familiar ou inédita, simples ou complexa, e ainda se possui valor hedônico. Talvez, o movimento representado numa obra de arte também se caracterize como uma propriedade colativa.

A forma de apresentação de uma obra de arte ao expectador também deve ser considerada. De acordo com a Nova Estética Experimental a apresentação da obra pode ser baseada em duas abordagens: sintética e analítica. A abordagem sintética consiste na seleção de fragmentos de uma obra para fazerem parte da apreciação estética, e permite a manipulação ou o isolamento destas partes. Na abordagem analítica, as obras são utilizadas integralmente, sem qualquer tipo de manipulação mantendo-se as características genuínas da obra (Berlyne, 1974).

Baseados na abordagem proposta por Berlyne (1974), Nather (2006) e Nather e Bueno (2006a, b) usaram estímulos visuais, duas fotografias de bonecas em diferentes posições $^{12}$, uma sentada e a outra em pé sugerindo, respectivamente, uma menor e uma maior representação de movimento. Os participantes deste estudo, não treinados em artes visuais, deveriam reproduzir o tempo de apresentação dos estímulos. Os resultados mostraram que a fotografia com menor representação de movimento foi julgada mais curta que aquela com maior representação de movimento. Este resultado sugeriu que a percepção do movimento representado numa imagem estática deve suscitar um processamento semelhante à visualização de um movimento real.

Nather (2006) e Nather e Bueno (2011a) verificaram ainda possíveis diferenças nos julgamentos de representação de movimento dos participantes ao observarem pinturas de bailarinas do artista Edgar Degas. Os participantes foram divididos em dois grupos sendo que o primeiro grupo observou as pinturas sob a abordagem analítica e o segundo grupo observou as imagens sob a abordagem sintética. Neste grupo as imagens dos quadros foram manipuladas de forma que a bailarina ficasse no centro da foto, os elementos contextuais das pinturas, como a sala de aula ou paisagens em segundo plano, foram excluídos. A análise dos resultados das escalas de diferencial semântico mostrou que tanto no grupo que observou as imagens sob a abordagem sintética quanto o grupo que observou as imagens sob a abordagem analítica o estímulo que representava uma bailarina parada foi julgado com menor representação de movimento do que o estímulo

\footnotetext{
${ }^{12}$ As fotografias utilizadas foram tiradas de fragmentos da obra original "O Espelho" que é composta de 6 duplas de bonecas totalmente pintadas, cada uma com uma cor. A autoria da obra é do artista plástico Francisco Carlos Nather. "O Espelho" participou do Mapa Cultura Paulista (Edição 2003/2004) na exposição realizada no Centro Cultural Oswald de Andrade na cidade de São Paulo.
} 
que representava uma bailarina em pose de balé. Isto indica que as diferentes intensidades de movimento representado nas imagens continuam sendo percebidas independentemente da abordagem utilizada ser sintética ou analítica.

Nather e Bueno (2008), com o objetivo de obter uma escala da intensidade de movimento do corpo humano representado em estímulos visuais estáticos, desenvolveram uma escala de representação de movimentos corporais e elaboraram a Body Movement Ranking Scale (BMRS). Neste estudo, foram utilizadas fotografias de 16 esculturas de bailarinas do artista impressionista Edgar Degas, em exposição no acervo do Museu de Arte de São Paulo (algumas das imagens utilizadas neste estudo podem ser vistas na Figura 3). Os participantes foram divididos em dois grupos de quatorze indivíduos, sendo um grupo treinado em dança e outro não treinado. As imagens foram exibidas individualmente a todos os participantes e, após cada exibição, os sujeitos deveriam preencher uma escala de diferencial semântico (tipo Linkert de sete pontos), referente à intensidade do movimento representado em cada imagem. Os resultados permitiram a organização das imagens em ordem crescente de intensidade dos movimentos representados nas esculturas. A imagem julgada com menor intensidade de movimento (uma bailarina parada em pé: Figura 3a) recebeu pontuação 1.5 , enquanto que a imagem julgada com maior intensidade recebeu pontuação 6.0 (bailarina na posição de um grande Arabesque ou Penché: Figura 3g). As imagens de esculturas de bailarinas em diferentes posições de Arabesques (Figuras 3e, f e g) foram agrupadas entre as maiores pontuações (5.0 e 6.0-pontos) tanto para o grupo de indivíduos treinados em dança quanto para o grupo de indivíduos não treinado em dança. Este resultado mostrou que as diferentes intensidades de movimento representado nas imagens são percebidas independentemente do treinamento ou do conhecimento do passo de Balé que representam.

Em seus trabalhos, Nather e Bueno (2006b, 2008, 2010 e 2011a, b) utilizaram imagens de obras de arte que retratavam diferentes movimentos do Balé Clássico para verificar os efeitos da observação destas obras na estimação subjetiva de tempo. Os autores concluíram que as diferentes intensidades de movimento representado nas obras de Edgar degas afetavam a estimação subjetiva de tempo dos participantes. Seria possível relacionar a intensidade de movimento representado nestas imagens com a própria execução do passo de Balé que representam? E ainda, o conhecimento do passo e da forma como são executados não seria uma maneira de explicar os efeitos desta imagem na percepção subjetiva de tempo? 
A elaboração da BMRS permitiu classificar as imagens das esculturas de acordo com a intensidade de movimento nelas representado. A relação entre a intensidade de movimento representado na imagem e o passo de balé que representa é coerente com a dinâmica dos passos quando realizados por um bailarino. $\mathrm{O}$ estímulo neutro (4.0 - pontos, ver Figura 3c), utilizado por Nather e Bueno (2008), denominado como Primeira posição do grande Arabesque é considerado um passo de execução simples, assim como o estímulo 3.0-pontos (Prelúdio para dança, com a perna direita para frente: Figura 3b). Diferentemente, o estímulo 6.0-pontos é considerado no Balé Clássico como um exercício de alto grau de dificuldade (ver Figura 3g). Estas três esculturas foram consideradas em grupos diferentes em relação ao critério Movimento (Nather \& Bueno, 2008) e também possuem características de execução bem distintas de acordo com a técnica do Balé Clássico. Desta forma, a descrição das características dessas imagens torna-se necessária para o conhecimento das peculiaridades de cada escultura.

O Estímulo 4.0-pontos, considerado como Estímulo Neutro de acordo com a BMRS (ver Nather \& Bueno, 2008), nomeado de acordo com a técnica do Balé Clássico como Primeiro Arabesque à terre, ou seja, Primeiro Arabesque com a perna apoiada no chão, consiste em uma posição inicial que prepara o bailarino para realizar um primeiro Arabesque en lair, ou seja, Arabesque com a perna no ar, resultante do movimento de erguer a perna que está localizada atrás do tronco a partir de um ângulo de $45^{\circ}$ da perna de base.

O Estímulo 3.0-pontos, denominado de Prelúdio para dança com a perna direita para frente, representa o passo Tendu devant ouvert, que se refere à colocação das pernas não cruzadas e à extensão de um dos pés à frente do corpo. Este passo pode ser combinado com diferentes posições de braços, mas nesta escultura, apresenta os braços em $3^{a}$ posição. Quanto à utilização do passo representado nesta obra, ele pode ser uma introdução, ou seja, o começo de uma apresentação ou um passo intermediário entre dois outros. $\mathrm{O}$ andamento musical para sua execução pode ser tanto rápido (Allegro) quanto lento (Adágio).

O Estímulo 6.0-pontos, denominado Terceiro tempo da grande Arabesque, representa o passo Penché que é resultado de uma elevação maior da perna que está erguida, atingindo um ângulo de $180^{\circ}$ em relação à perna que está no chão. Sua execução é complexa, e sua aprendizagem é efetiva quando o bailarino já possui boa consciência corporal, bom tônus muscular e elasticidade. Por isso, é ensinado em aulas 
de Balé avançado. As posições das pernas ilustram um grande Arabesque, devido à maior inclinação da perna que está no ar. Um Arabesque é caracterizado quando uma perna desempenha a função de base e a outra se eleva em Derriére (atrás do corpo) a $45^{\circ}$ ou $90^{\circ}$ graus em relação à perna de base, o bailarino deve esforçar-se para manter o tronco na mesma posição, como se estivesse com as duas pernas no chão o que exige força das costas e do abdômen. No Penché mantém-se esta figura acrescentada de maior inclinação do tronco e de maior elevação da perna que está erguida, sendo objetivo do bailarino formar um ângulo de $180^{\circ}$ graus entre a perna en l'air e a perna de base. A posição de braços representada nesta escultura é de um $1^{\circ}$ Arabesque.

Geralmente o Penché é executado em andamentos musicais lentos do tipo Adágio. Como sua execução é complexa, e possui uma sequiência de passos intermediários, sua performance exige maior tempo. Obviamente, o professor ou o coreógrafo pode explorar outros andamentos, os quais seriam uma variação desta base comum de aprendizagem e exigiriam o máximo de aperfeiçoamento técnico do bailarino. Pessoas treinadas em dança ao observarem as imagens das esculturas de Degas, provavelmente, relacionarão a imagem observada ao passo (nomenclatura, execução) correspondente na técnica do balé clássico, assim como ao andamento musical relacionado a cada passo.

Nas pinturas e esculturas de Degas o movimento do Balé Clássico encontra-se paralisado. Seria possível que a simples representação de movimento em uma imagem estática evoque uma sensação de movimento real? Como a ciência tem abordado a percepção de movimento em imagens estáticas?

Algumas pesquisas vêm abordando a representação de movimento em imagens estáticas e como essa representação dinâmica é percebida por humanos. Estes estudos abordam a percepção do movimento estático sob o enfoque de movimentos irreversíveis (Freyd, 1983), de movimentos coerentes (Shiffar \& Freyd, 1993), de mecanismos cognitivos (Freedberg \& Gallese, 2007) e neurais envolvidos (Kourtzi \& Kanwisher, 2000) e ainda sob uma abordagem temporal (Nather \& Bueno, 2006b, 2011b).

Freyd (1983) verificou se a representação de movimento também ocorreria sob condições estáticas utilizando fotografias de ações congeladas. Neste estudo, foram utilizados como estímulos trinta pares de fotografias, cada par contendo uma imagem de uma ação de "antes" e "depois" do movimento como, por exemplo, uma fotografia de uma pessoa pulando de uma parede no início da queda e a outra fotografia, com a mesma pessoa, no final da queda. As sequiências de apresentação foram randomizadas 
de forma que metade eram compostas de seqüências antes - depois e a outra metade de seqüencias depois - antes. Os participantes deveriam responder se a segunda imagem da ordem de apresentação era a mesma da primeira. Os resultados revelaram que os participantes rejeitaram menos as fotografias de "depois" do que as fotografias de "antes". Estes resultados indicam que seres humanos representam o movimento implícito em imagens estáticas e que as representações de movimento em si podem ser percebidas como dinâmicas.

Pesquisas vêm estudando os processos neurais envolvidos na percepção de movimento de seres humanos com o objetivo de especificar as áreas cerebrais envolvidas na percepção visual de imagens de corpos humanos (Urgesi et al., 2000; Buetti, Bahami \& Walsh, 2008). As áreas cerebrais envolvidas na percepção visual de movimento em imagens estáticas e de fotografias de partes de corpos humanos (por exemplo, mãos e braços) têm sido discutidas por diferentes autores (Kourtzi \& Shiffar, 1999; Kourtzi \& Kanwisher, 2000; Verffaille \& Daems, 2002).

Apoiados no estudo de Freyd (1983) e por pesquisas da área de neurofisiologia que indicam que uma das principais áreas cerebrais envolvidas na análise visual de movimento é a área visual temporal medial/córtex temporal superior medial (MS/MST) (ver mais em: Tootell et al., 1995; Duppont et al., 1994) Kourtzi e Kanwisher (2000) verificaram se estas áreas cerebrais envolvidas na análise do movimento físico de um estímulo também estão engajadas no processamento da informação dinâmica de imagens estáticas com representação de movimento. Os pesquisadores utilizaram o recurso metodológico de functional Magnetic Resonance Imaging (fMRI) para localizar e mensurar a atividade da área MS/MST do córtex cerebral em cada um dos participantes da pesquisa, enquanto observavam imagens estáticas de atletas em ação ou em repouso. Para desvincular a imagem dos atletas da ação representada os participantes também observavam imagens de pessoas em repouso, animais e paisagens. Os resultados da pesquisa sugeriram que as áreas cerebrais envolvidas na análise do movimento físico dos estímulos podem também ser automaticamente ativadas por imagens estáticas que representam movimento como, por exemplo, a imagem estática (fotografia) de um atleta parado e outra do mesmo atleta arremessando a bola (Anexo III).

A pesquisa de Kourtzi e Kanwisher (2000) evidencia que a percepção visual de movimento pode estar relacionada a um grupo específico de células neurais, os neurônios espelho, que são ativados mediante a visualização de movimento (revisão em 
Rizzolatti \& Graigheiro, 2004). Freedberg e Gallese (2007) propuseram teoricamente relacionar a descoberta do mecanismo de neurônios espelho à experiência estética, envolvendo ainda conceitos de empatia e embodiment ${ }^{13}$. Os autores propõem que "o elemento crucial da resposta estética consiste na ativação de mecanismos incorporados e na simulação de ações, emoções e sensação corporal e que estes mecanismos são universais" (Freedberg \& Gallese, 2007 p. 197). Para os autores a nossa capacidade de pré-racionalizar o sentido das ações, emoções e sensações das pessoas depende da simulação incorporada, que seria um mecanismo funcional através do qual as ações, emoções e sensações que vemos podem ser ativadas em nossas próprias representações internas dos estados corporais que são associados com o estímulo que é apresentado, ou seja, é como se estivéssemos experienciando a mesma sensação ou emoção da imagem que observamos.

Assim, ao apreciarmos um quadro que retrate um homem sendo torturado incorporamos a dor transmitida pelo quadro, é como se sentíssemos a própria dor. Esta sensação por algo que não está acontecendo realmente, mas que está sendo observado em uma obra de arte é chamado de empatia por vários autores (Visher, 1873; Wolfflin,1886; Lipps, 1903 e Pinotti, 2007 apud Freedberg \& Gallese, 2007). Freedberg e Gallese (2007) concluíram que respostas de empatia automática constituem o nível básico da resposta a imagens e obras de arte. A base dessa resposta é o processo de simulação incorporada que possibilita a experienciação do conteúdo intencional e emocional das imagens. Provavelmente, os processos de empatia e embodiment possuam como substrato neural os mecanismos de neurônios espelho.

Recentemente, Nather et al. (2011) buscaram verificar se a percepção de uma imagem estática de corpos humanos em distintas posições poderia afetar a estimação de tempo através da ativação da simulação mental do movimento associado à posição. Para tanto, os autores utilizaram imagens das esculturas de bailarinas de Degas uma representando um grande passo de Balé (Penché, ver Figura 3g) e outra representando uma bailarina em repouso. Os resultados deste estudo mostraram que as distorções temporais foram maiores para a imagem contendo um grande movimento corporal (passo Penché). Os autores concluíram que a percepção da duração temporal muda em função do movimento induzido pela posição corporal, provavelmente, porque a imagem com uma grande posição corporal acionaria mecanismos de simulação mental deste

\footnotetext{
${ }^{13}$ A palavra inglesa embodiment ainda não possui uma tradução exata para a Língua Portuguesa, mas refere-se à ação de incorporar um movimento que está sendo observado, seja ele implícito ou real.
} 
movimento através dos mecanismos de embodiment e empatia (Freedberg \& Gallese, 2007) resultando em uma demanda maior de esforço e arousal $^{14}$.

Pessoas treinadas em dança, ao observarem imagens de corpos humanos em diferentes posições de balé, teriam a mesma simulação mental de pessoas não treinadas em dança? O processo de aprendizagem da técnica do Balé Clássico não resultaria em diferentes experiências de embodiment e empatia? Vários estudos sobre as possíveis diferenças perceptuais entre indivíduos treinados e não treinados em artes vem buscando elucidar os processos envolvidos na observação de estímulos familiares ou não para os participantes.

Calvo-Merino et al. (2005) analisaram os processos cerebrais de humanos ao observarem bailarinos em movimento e como o conhecimento prévio da ação observada pode influenciar nestes processos. Em seus experimentos utilizando o recurso de fMRI, para detectar as áreas cerebrais que eram ativadas em bailarinos profissionais, praticantes de capoeira e indivíduos leigos nestas duas atividades, foi verificado que os indivíduos que possuíam conhecimento da dança observada (familiaridade) apresentaram grandes ativações bilaterais no córtex pré-motor, nos sulcos intraparietais e em outras regiões cerebrais, o que não ocorria quando assistiam movimentos não familiares. Tal resultado indica que o processo de aprendizagem, que permite o conhecimento técnico e artístico da movimentação observada (técnica do balé clássico e da capoeira), pode influenciar diretamente na percepção de movimento do indivíduo.

Cross et al. (2006) realizando estudos com bailarinos utilizando seqüências de dança ensaiadas e não ensaiadas, através do recurso do fMRI, verificaram um aumento da atividade cerebral (parietal e pré-motora) correspondente à habilidade de executar uma ação aprendida. Em outro estudo sobre balé clássico, Calvo-Merino et al. (2006) pesquisaram a influência da familiaridade visual e motora ao se observar determinada ação, acrescentando ainda, possíveis diferenças de ativação de áreas cerebrais distintas entre os gêneros masculino e feminino.

Nather, Bueno e Bigand (2009) verificaram que existem diferenças nas estimações temporais de imagens estáticas de esculturas em posição de balé entre indivíduos treinados em dança, treinados em artes e pessoas leigas. Provavelmente, o conhecimento e a familiaridade da dança podem afetar diferentemente a ativação cerebral dos indivíduos no processamento da estimação temporal, uma vez que a

\footnotetext{
${ }^{14}$ A palavra inglesa Arousal (ativação interna) significa 'um estado interno alterado' subjacente aos estados emocionais positivos ou negativos que ocorrem quando se dá o encontro obra-expectador.
} 
percepção de pessoas leigas e de pessoas não leigas em dança pode envolver distintos processamentos relacionados à percepção de movimento. Para Brown, Martinez e Parsons (2005) existe uma rede interativa de áreas cerebrais que são ativadas durante movimentos rítmicos e padrões espaciais que são integrados ao dançar. De acordo com os autores a aprendizagem de movimentos complexos resulta em alterações funcionais e conectivas na reorganização e redistribuição de processos neurais.

O conceito de "Mental Imagery" proposto por Kosslyn (1981; 2005) e Kosslyn, Berhrmann e Jeannerods (1995) pode contribuir para a elucidação da existência de distintos processamentos oriundos da observação de imagens de corpos em movimento de pessoas treinadas e não treinadas em dança. Segundo os autores, a imagem mental visual seria "ver" na ausência do input sensorial imediato apropriado e a imagem mental auditiva seria "escutar" mesmo na ausência do input sensorial imediato apropriado para este sentido. Dessa forma, pode-se inferir que pessoas treinadas em dança, bailarinos, possuem em seu repertório a imagem mental do movimento assim como da música que acompanha este movimento, enquanto que pessoas não treinadas em dança não têm em seu repertório a mesma imagem mental. A existência de uma imagem mental relacionada ao estímulo observado no repertório do indivíduo provavelmente resulta em diferentes processamentos no momento da observação de imagens de corpos humanos em movimento.

No Balé Clássico a execução de cada passo demanda um tempo específico entre seu começo e seu fim. O tempo de cada movimentação corporal é baseado no andamento musical no qual o movimento está sendo realizado. Portanto, é na simultaneidade movimento/música que surge a arte da dança. $\mathrm{O}$ efeito da aprendizagem do Balé já foi verificado em pesquisas que relacionaram a percepção visual de movimento e a ativação das áreas cerebrais envolvidas no processamento desta informação. Dessa forma, haveria também um efeito do treinamento em Balé Clássico nas estimações temporais de imagens estáticas com diferentes passos de Balé representados? 


\section{O estudo de Tempo Subjetivo}

A percepção de tempo é resultado de sensações e percepções internas e externas do indivíduo sendo essencial para a orientação do ser humano. Como não existe um órgão específico que realize o processamento temporal, estados de consciência que analisam intervalos de tempo entre eventos sucessivos ou eventos seqüenciados são utilizados em pesquisas que visam elucidar os processos subjacentes à estimação temporal em humanos. Estas pesquisas enfatizam o componente subjetivo da percepção de tempo (Block \& Zakay, 1997; Fraisse, 1984; Zakay, 1990).

Para Zakay (1990) o tempo subjetivo pode ser estudado através de estimações temporais, embasadas na quantidade de mudanças percebidas pelo sujeito no momento da estimação, havendo uma tendência de que quanto maior a quantidade de mudanças percebidas e de informação contida no estímulo maior será a estimação temporal. A estimação de um evento envolve a utilização de recursos da memória, pois para que se analise a duração de um intervalo de tempo é necessário relacionar passado e presente. Estímulos com duração inferior a 100ms são percebidos como instantâneos, ao contrário, estímulos com duração superior à 5 s envolvem recursos da memória (Block, 1990).

A atenção, juntamente com a memória, é um processo cognitivo fundamental na estimação temporal. Assim, a natureza da estimulação, as características, a intensidade e a modalidade do intervalo de tempo podem resultar em diferentes processamentos temporais. Se a estimação temporal exceder o tempo de duração real houve uma superestimação, contrariamente, se o evento é estimado com duração inferior ao tempo real houve uma subestimação (Block, 1990; Zakay \& Block, 2004).

Fraisse (1984) relatou que sons parecem ser mais longos do que luzes e concluiu que estímulos auditivos parecem ser mais longos do que estímulos visuais. Klapproth (2002) verificou que estímulos acústicos tendem a serem estimados mais precisamente do que estímulos visuais e sugeriu que esta diferença se deve à própria natureza do estímulo e, portanto, julgamentos de estimação temporal são determinados não somente pela duração objetiva, mas, também pelas características não temporais dos estímulos. A apresentação conjunta de estímulos acústicos e visuais pode revelar, experimentalmente, se existe uma prevalência de um estímulo sobre o outro em processos perceptivos. 
Fraisse (1963) propôs que a duração psicológica é composta de mudanças psicológicas assim, um contexto não familiar promove mais mudanças contextuais e, portanto, maiores estimações. A duração é o parâmetro mais enfatizado na pesquisa de tempo subjetivo, porque os julgamentos de duração requerem atenção e memória e por isso podem revelar os processos cognitivos subjacentes à estimação temporal (Nather, 2006). Existem dois paradigmas que podem ser utilizados para se estimar o tempo subjetivo: o retrospectivo e o prospectivo. Em cada um destes paradigmas, diferentes estratégias de estimação temporal poderão ser adotadas pelo indivíduo, pois divergem na maneira de experienciar o tempo. O paradigma retrospectivo seria a duração relembrada pelo sujeito e o paradigma prospectivo seria a duração experienciada. Ambos estão relacionados ao fator expectativa, embora o primeiro esteja mais relacionado à memória e o segundo a atenção (Brown, 1985; Block, 1990; Graf \& Grondin, 2006).

Todos os modelos mais discutidos na literatura de tempo subjetivo indicam que os julgamentos de duração dependem da capacidade de armazenamento da memória e do esforço cognitivo necessário para a compreensão do estímulo observado. O modelo de Armazenamento proposto por Ornstein (1969) baseia-se na afirmação de que intervalos de tempo iguais parecerão ter diferentes durações porque um é mais complexo e necessita de mais esforço para armazenamento na memória. Thomas e Weaver (1975) e Underwood e Swain (1973) propuseram o modelo de Atenção postulando que a estimação depende da quantidade total de esforço de atenção requerido por um dado estímulo, ou seja, estímulos complexos parecem ter maior duração porque requerem uma atenção seletiva maior. Block (1985) propôs o modelo de Mudança Cognitiva, o qual supõe que a duração estimada aumenta com o número de mudanças de estratégias de processamento da informação do estímulo pelo indivíduo ou por mudanças nas demandas da tarefa. O modelo de Contraste foi proposto por Boltz (1989) e diz que a estimação temporal está relacionada à estrutura na qual um evento é organizado, gerando a possibilidade de previsão do que está por vir.

Triesman (1963) e Gibbon, Chuch e Mech (1984) propuseram o modelo de relógio interno. De acordo com este modelo, um marcapasso produz séries regulares de pulsos que aumentam de acordo com o nível de arousal (ativação) do organismo e um contador grava o número de pulsos até certo ponto, então o resultado vai para um armazenador ou um mecanismo de comparação. Um mecanismo seletivo verbal (memória de logo prazo contendo rótulos verbais) utiliza-se da informação armazenada. 
O modelo de relógio interno é muito aceito dentre os modelos teóricos de estimação temporal (Graf \& Grondin, 2006; Droit-Volet et. al., 2004; Grondin, 2010), entretanto, alguns autores como Brown (1997) e Fortin e Rousseau (1987) levantam críticas aos modelos de relógio interno alegando que são uma

\begin{abstract}
"visão simplista de processos complexos que subjazem o tempo psicológico (...). Modelos cognitivos, os quais propõem que vários fatores influenciam a duração relembrada, podem explicar a imprecisão das estimações humanas mais convincentemente do que o modelo do relógio interno" (BLOCK, 1990 p. 17).
\end{abstract}

Buscando explicações para o conjunto de dados encontrados em pesquisas que abordam a percepção temporal de humanos, Zakay e Block (1997) propuseram o modelo de Portão Atencional que combina os componentes do marcapasso e atencionais em um modelo integrado, no qual se enfatiza que a duração temporal pode requerer que o indivíduo divida sua atenção entre o processamento de informação não temporal (estímulo) e o processamento de informação temporal. Assim, a magnitude dos julgamentos de duração prospectiva é influenciada, principalmente, pela quantidade de atenção que a pessoa utiliza para processar a informação temporal.

Para Ali (2008) os modelos baseados no relógio interno e aqueles não baseados podem ser complementares na busca de se compreender a característica plástica do tempo subjetivo. Muitas são as tentativas de se explicar o processamento do tempo subjetivo em humanos, mas até o momento, nenhum modelo consegue abranger toda a complexidade da experiência temporal ainda que todos contribuam para elucidar alguns aspectos da estimação temporal levantados em pesquisas de tempo subjetivo.

Obras de arte como músicas, filmes, pinturas e esculturas vem sendo utilizadas como estímulos em pesquisas de tempo subjetivo. Os diferentes elementos constituintes de músicas clássicas como as escalas musicais (Ramos, 2007), as modulações de trechos musicais próximos e distantes (Firmino, 2003), as variações tonais (Lelis, 2002; Firmino \& Bueno, 2008, 2009) e o contexto rítmico (Jones \& Boltz, 1989) permitem o estudo destes diferentes parâmetros musicais separadamente e a verificação de seus efeitos na estimação subjetiva de tempo. Os resultados destes estudos indicam que diferentes processos participam da percepção temporal de estímulos acústicos.

Outros estudos mostraram que diferentes intensidades de movimento em obras de arte, imagens estáticas bidimensionais (Nather, 2006; Nather \& Bueno, 2006a, b, 2008 e 2010; Nather, Giannetti, \& Bueno, 2010), resultam em diferentes estimações 
temporais. A característica dos estímulos visuais utilizados nos experimentos de estimação temporal é um fator importante. Para Eagleman e Pariyadath (2009) a duração subjetiva é modulada pelas propriedades do estímulo como, por exemplo, o tamanho, o brilho e o movimento. Os efeitos da aprendizagem na estimação temporal também foram verificados. Cupchick e Gebotys (1988) utilizaram obras de arte de artistas impressionistas como Degas e Monet com intuito de analisar os julgamentos de duração das exposições. Os resultados indicaram que pessoas treinadas em artes tenderam a subestimar temporalmente as obras, enquanto que pessoas leigas em artes superestimaram principalmente as obras julgadas mais complexas. Os autores confirmaram a hipótese de que os julgamentos de duração da exposição refletem a quantidade de esforço perceptivo/cognitivo necessário para apreciar a pintura. Assim, pessoas treinadas em artes demandariam menor esforço perceptivo/cognitivo para apreciar as obras o que acarretaria em subestimações temporais.

A utilização de obras de arte em pesquisas de tempo subjetivo vem contribuindo para a elucidação dos processos subjacentes a percepção temporal. Mas como utilizar experimentalmente obras de arte em pesquisas de tempo subjetivo?

\subsection{Tempo Subjetivo e a Estética Experimental}

A "Nova Estética Experimental" (Berlyne, 1974), definida como o estudo de obras de arte ou outros fenômenos estéticos por meio de experiências que analisam as reações dos indivíduos aos estímulos artísticos, vem sendo utilizada como uma ferramenta para desvendar os processos envolvidos na percepção subjetiva de tempo em diversos estudos envolvendo músicas (Bueno, Firmino \& Engelman, 2002; Bueno \& Ramos, 2007; Bueno \& Cocenas, 2010), e imagens de pinturas e esculturas (Cupchick, 1976; Cupchik \& Getbotys, 1988; Nather \& Bueno, 2006a, b, 2008, 2010, 2011).

Nather e Bueno (2006b) utilizaram duas imagens de bonecas em diferentes posições uma sentada e outra em pé e solicitaram aos participantes que reproduzissem o tempo de duração de cada uma das imagens sob o paradigma prospectivo. Com o tempo de apresentação de 36 segundos, a imagem da boneca sentada obteve estimação média de $31,52 \mathrm{~s}$ e a boneca em posição em pé obteve estimação média de $34,51 \mathrm{~s}$. A primeira foi considerada estatisticamente diferente da segunda, sendo ambas subestimadas em 
relação ao tempo real de apresentação. Estes resultados indicaram que quanto maior o movimento representado na imagem maior a estimação temporal. Ainda neste estudo, quando o tempo de exposição das imagens foi de $18 \mathrm{~s}$ as imagens não foram consideradas estatisticamente diferentes entre si. Este resultado sugere que em trabalhos de tempo subjetivo que envolvam obras de arte deva existir um limiar temporal, a partir do qual a apreciação artística e as peculiaridades da obra sejam percebidas e processadas pelo indivíduo (Cupchick \& Getbotys, 1988).

Em outro trabalho, Nather e Bueno (2008) utilizaram imagens da Body Moviment Ranking Scale (BMRS) para verificar se intensidade de movimento representado nas esculturas de bailarinas de Edgar Degas afetaria a estimação subjetiva de tempo dos participantes. Participaram do estudo 124 estudantes não treinados em dança ou artes visuais, os quais realizaram estimações temporais no paradigma prospectivo $^{15}$ através do método de reprodução ${ }^{16}$ de tempo subjetivo. Foi constatado que as imagens previamente julgadas com maior representação de movimento obtiveram estimações temporais maiores do que as imagens com menor representação de movimento. Assim, a estimação temporal dos indivíduos aumentava conforme a escala de movimento também crescia em pontuação. A análise entre estímulos revelou que a imagem da bailarina em posição em pé e parada (1.5-pontos) foi estimada diferentemente da imagem que representava um movimento de dança espanhola (4.5pontos), sendo ambas significativamente diferentes da imagem da bailarina em Arabesque (Penché: 6.0-pontos) (Figura 3a, 3d, e 3g, respectivamente, p.19).

Os resultados das estimações temporais em relação ao tempo real de apresentação de $36 \mathrm{~s}$ revelaram que as diferentes intensidades de movimento representadas nas esculturas de Degas afetaram as estimações temporais dos observadores. A imagem da bailarina em posição em pé e parada (1.5-pontos) foi subestimada, a imagem que representava uma dança espanhola (4.5-pontos) foi estimada com a mesma duração do tempo real e a imagem da bailarina em Arabesque (Penché) foi superestimada (6.0-pontos). Os resultados revelaram que a as diferentes

\footnotetext{
${ }^{15}$ No paradigma prospectivo os sujeitos são informados que realizarão estimações temporais antes do experimento ser iniciado diferentemente, no retrospectivo, o participante só é informado sobre esta tarefa após a realização do teste experimental.

${ }^{16}$ No método da produção, o sujeito 'lida' com o tempo contínuo e na reprodução com o tempo passado. Estes métodos podem fornecer julgamentos temporais inversos: subestimações na produção podem ser superestimações na reprodução.
} 
intensidades de movimento representadas nas esculturas de Degas afetaram as estimações temporais dos observadores.

As imagens das esculturas com maior representação de movimento (grande Arabesque: 6.0-pontos) tendem a ser superestimadas enquanto que as imagens de esculturas com menor representação de movimento (bailarina parada: 1.5-pontos por exemplo) tendem a ser subestimadas. Imagens com intensidade de representação de movimento que obtiveram pontuações medianas de acordo com a escala (Prelúdio para dança: 3.0-pontos, ver Figura 3c) foram estimadas com a mesma duração do tempo real de apresentação. Este resultado indica que quanto maior a intensidade de movimento de corpos humanos representados em uma obra estática maior será a percepção temporal do observador.

Nather, Bueno e Bigand (2009) utilizaram o recurso metodológico de eye tracking, o qual permite o registro dos focos de observação realizados pelos olhos dos participantes. O objetivo da pesquisa foi examinar os movimentos oculares de participantes treinados e não treinados em dança ou artes visuais enquanto estimavam o tempo de apresentação de imagens de esculturas em bronze de bailarinas do artista Edgar Degas. Os estímulos selecionados foram as imagens 1.5-pontos, 3.0-pontos e 6.0pontos (Nather e Bueno ,2008). Os resultados revelaram que ao observarem imagens com maior representação de movimento (6.0-pontos) a atenção dos participantes foi mais dirigida para os braços e pernas enquanto que as imagens com menor representação de movimento (1.5-pontos e 3.0-pontos) foram mais observadas nas partes do tronco e cabeça. A análise das estimações temporais revelou que os participantes treinados em dança subestimaram a imagem 6.0-pontos enquanto que participantes treinados em arte a estimaram com a mesma duração do tempo real. Os participantes não treinados em nenhuma das modalidades superestimaram a imagem 6.0-pontos. Estes resultados revelaram diferenças nas estimações temporais de pessoas treinadas e não treinadas em artes.

Nather et al. (2011), através de testes de bissecção temporal ${ }^{17}$, utilizaram duas imagens da BMRS: uma bailarina em posição de repouso, ou seja, com pouca representação de movimento e outra com uma bailarina em uma grande posição de balé (respectivamente, Figuras $3 \mathrm{a}$ e $3 \mathrm{~g}$ ). Os resultados revelaram que a apresentação da bailarina em grande posição de balé foi julgada maior do que a da bailarina em posição

\footnotetext{
${ }^{17}$ Neste experimento o participante deve comparar a duração temporal de um estímulo observado com outras duas durações previamente estabelecidas em um momento de treino.
} 
de repouso. Para os pesquisadores quanto maior o movimento representado na imagem maior o esforço necessário para incorporar a ação observada, o que resulta em maiores ativações internas (arousal). Os autores explicam seus resultados a partir do modelo do relógio interno: quando o sistema nervoso está em arousal o sistema do relógio acelera e mais unidades de tempo são acumuladas o que resulta em maiores estimações temporais.

De uma maneira geral, os trabalhos que relacionaram a percepção de movimento em obras de arte visuais estáticas evidenciaram que o movimento modula a experiência temporal dos observadores e quanto maior o movimento representado maior será a estimação subjetiva de tempo. A existência de um efeito do treinamento em artes também foi verificada nas estimações temporais, pessoas treinadas tendem a subestimar os estímulos enquanto pessoas não treinadas tendem a realizar superestimações (Cupchick \& Getbotys, 1988; Narher, Bueno \& Bigand, 2009).

Obras de arte que representam corpos humanos em posições de Balé, possivelmente, evocam sensação de movimento porque a execução de cada passo demanda um tempo específico entre seu começo e seu fim. Dessa forma, imagens estáticas de bailarinas em posição de balé possuem propriedades colativas (como, por exemplo, o possível deslocamento dos membros até chegar à posição representada) que induzem a uma sensação de movimento, que mesmo não sendo real, é percebido. Na arte da dança, o movimento é resultado de passos realizados sob um determinado ritmo musical. O que os estudos que utilizaram músicas clássicas como estímulos têm revelado sobre os processos envolvidos na estimação subjetiva de tempo?

Bueno, Firmino e Engelman (2002) utilizaram diferentes trechos de músicas clássicas para estudar a estimação subjetiva de tempo de não músicos. Os resultados desta pesquisa mostraram que as músicas mais complexas, que necessitariam maior esforço cognitivo, foram julgadas mais longas do que as músicas mais simples. Foi evidenciado que as diferentes características das composições musicais como as escalas, as modulações, as variações tonais e o contexto rítmico podem funcionar como marcadores para as estimações temporais dos indivíduos. Bueno e Ramos (2007) verificaram que músicas clássicas em diferentes modos também acarretam diferenças nas estimações temporais de indivíduos não músicos. Modos dissonantes (considerados desagradáveis como, por exemplo, Locrian) foram considerados mais longos do que os modos consonantes (considerados agradáveis como, por exemplo Aeolian e Eolian). 
Estes resultados indicam que estímulos agradáveis tendem a encurtar a experiência temporal dos participantes.

Com o objetivo de identificar os fatores psico-musicais subjacentes a estimação temporal de músicas do repertório barroco, clássico, romântico e moderno Cocenas et al. (2010) utilizaram como estímulos dezesseis trechos de músicas clássicas em diferentes andamentos (rápidos e lentos) e solicitaram a quarenta e oito participantes, músicos e não músicos, que escutassem as músicas (com duração de vinte segundos cada) e depois agrupassem aquelas que julgassem com duração temporal semelhante. A análise dos dados revelou o agrupamento das músicas em um grupo de andamento rápido e outro grupo de andamento lento. Para North, Hargreaves e Heath (1998), músicas de andamento rápido têm maior quantidade de informação e músicas de andamento lento possuem menos informação o que pode resultar em diferenças nas estimações temporais. Buscando testar esta hipótese, os autores investigaram os efeitos de andamentos rápidos e lentos nas estimações temporais dos participantes sob o paradigma retrospectivo. Os resultados demonstraram que não houve influencia do andamento nas estimações temporais, mas que o andamento lento levou a um maior grau de imprecisão nas estimações do que a música de andamento rápido.

Em resumo, os trabalhos que relacionaram obras de arte acústicas e percepção subjetiva de tempo revelaram que os diferentes parâmetros musicais modulam a experiência temporal. Músicas com maior quantidade de informação (mais complexas, como, por exemplo, constituídas de mais acordes por minuto) tendem a ser julgadas mais longas do que as músicas mais simples. A arte da dança emerge da simultaneidade movimento/música, o tempo de cada movimentação corporal é baseado no andamento musical no qual o movimento está sendo realizado. Portanto, a apresentação de uma imagem estática de uma bailarina em posição de balé em conjunto com uma música clássica promoverá a junção das propriedades musicais (andamento, complexidade, modos, etc) com as propriedades visuais (disposição dos membros, equilíbrio dinâmico). Qual seria o efeito da junção destes parâmetros, já discriminados na literatura, na apreciação estética dos observadores?

Os efeitos da interação obra-expectador na estimação subjetiva de tempo envolvem aspectos intrínsecos e extrínsecos ao observador. As características da obra de arte (propriedades colativas), a modalidade da obra utilizada (acústica visual, estática ou em movimento) e a forma como ela é apresentada (abordagem sintética ou analítica) constituem os aspectos extrínsecos ao observador. A quantidade de esforço cognitivo 
requerido para processar estas informações da obra de arte assim como o estado interno do expectador no momento da apreciação estética (emoções, atenção, arousal) constituem aspectos intrínsecos ao indivíduo.

A união das propriedades colativas de obras de arte acústicas e visuais resultaria em diferenças nas estimações temporais? E ainda, haveria prevalência de uma obra sobre a outra quando apresentadas simultaneamente? 


\section{A interação de estímulos acústicos e visuais}

A audição e a visão são sentidos fundamentais para a localização e identificação de objetos, e possuem um claro valor adaptativo. Seres humanos se utilizam de recursos visuais e auditivos para executarem ações do dia-a-dia como, por exemplo, escolher o melhor momento para atravessar uma rua com grande fluxo de carros. Assim, a interação som/imagem permite uma percepção mais apurada dos objetos existentes no meio externo (Bulking \& Groh, 2006). Alguns estudos têm buscado revelar os efeitos da interação som/imagem em ilusões perceptivas (Recanzone, 1998; 2009) e em processos temporais (Penney \& Gibbon, 2000; Droit-Volet, Tourret \& Wearden, 2004; Watanabe \& Shimojo, 2001; Krekelberg, 2003; Burr, Banks \& Morrone, 2009)

Bulking e Groh (2006) realizaram um levantamento de trabalhos envolvendo a interação visual e auditiva com o objetivo de discutir as influências visuais no processamento auditivo, sob aspectos comportamentais e neurofisiológicos. Os autores evidenciaram que o papel do sistema visual e auditivo é sobreposto e que tal sobreposição possibilita benefícios para captar informações sobre os objetos. Segundo os autores, a visão é excelente para informações espaciais, entretanto, não pode detectar objetos fora do campo visual. O sistema auditivo complementaria o sistema visual fornecendo informações sobre o que está fora do campo visual. Para os autores o cérebro parece combinar informação visual e auditiva para perceber objetos de forma mais apurada. Estudos recentes sobre a integração visual e auditiva (Meyer \& Wuerger, 1998, 2001; Stein et al., 1998; Spence \& Driver, 1996, 1997 e Mcdonald et al., 2000) sugerem que "o substrato neural para estas interações envolve o recrutamento de áreas cerebrais previamente pensadas como de predominância unimodal" (Bulkin \& Groh, 2006, p. 415).

Para Recanzone (1998, 2003 e 2009) ilusões audiovisuais podem ser utilizadas para investigar como a integração multisensorial ocorre, ressaltando que em muitos casos haverá a predominância de uma modalidade sensorial na percepção de um objeto ou de um evento multisensorial. Para exemplificar esta dominância o autor descreve o “efeito ventríloquo" (ventriloquism effect), no qual a percepção de um estímulo auditivo é percebida pela localização espacial de um estímulo visual. Assim, o efeito ventríloquo refere-se ao fato de que quando a localização espacial de um estímulo visual e auditivo está em conflito a visão, geralmente, domina a audição na localização espacial (sobre o 
efeito ventríloquo ver mais em: Howard \& Templeton, 1996; Welch \& Warren, 1980; Jack \& Thurlow, 1973; Radeau \& Bertelson, 1977 e 1978). No entanto, "para a localização temporal, o estímulo auditivo freqüentemente 'captura' o visual, o que se chama ventriloquismo temporal" (Burr, Banks e Morrone, 2009, p. 49), ou seja, o ventriloquismo temporal refere-se à influência exercida por um estímulo acústico na estimação temporal de um estímulo visual.

Burr, Banks e Morrone (2009) verificaram que grande parte dos estudos que abordavam o ventriloquismo temporal eram qualitativos, ou seja, mostravam a dominância mas sem quantificar a magnitude desta dominância e propuseram examinar este fenômeno de maneira quantitativa. Para tanto, os pesquisadores utilizaram três estímulos, um visual, um auditivo e um audiovisual através de testes de bissecção temporal. $\mathrm{O}$ estímulo visual consistia em um disco de $2 \mathrm{~cm}$ de diâmetro apresentado no monitor por $5 \mathrm{~ms}$ e o estímulo auditivo eram tons puros. Os autores verificaram que o som tende a dominar a percepção temporal de estímulos audiovisuais, mas este domínio não é total e pode variar de indivíduo para indivíduo, porque embora a dominância auditiva fosse qualitativamente prevista, a previsão quantitativa foi imperfeita.

Shams et. al (2000) verificaram o domínio da audição sobre a visão ao utilizarem como estímulos flashes de luz e sons de bip. Os autores verificaram que quando um flash de luz era apresentado com dois sons de bip os participantes relatavam ter visto dois flashes. Este resultado indica a prevalência do estímulo acústico sobre o visual. Outros trabalhos que utilizaram como estímulos flashes de luz e séries de tons também encontraram resultados semelhantes (Sekuler \& Sekuler, 1999; Shams et al., 2001; Berger et al. apud Burr, Banks \& Marrone, 2009). Para Andersen et al. (2004) nem sempre a audição domina a visão. Em situações nas quais o som está um pouco acima do limiar, ou seja, em volume mínimo para que possa ser escutado, a visão tende a exercer um domínio sobre a audição.

Meyer e Wuerger (2001) procuraram estabelecer novas evidências para a integração de estímulos auditivos e visuais em movimento e verificaram se o movimento auditivo (1) afetaria a sensibilidade da detecção do movimento visual, (2) se introduziria um viés de resposta ou (3) ambos. O estímulo visual utilizado foi um quadrado preto no qual 500 pontos se moviam numa trajetória aleatória e os sinais auditivos de movimento eram ruídos de duração de 1s. Os autores concluíram que a presença de movimento auditivo introduz um viés na percepção visual de movimento na direção do movimento auditivo e que uma mudança na sensibilidade é observada apenas 
quando o movimento auditivo e o movimento visual são combinados em velocidade e posição. Este resultado indica que a congruência entre os estímulos auditivos e visuais apresentados simultaneamente (mesma velocidade e posição) pode contribuir para que o estímulo acústico exerça um viés na percepção do estímulo visual.

Apesar de existirem trabalhos consistentes sobre a interação de estímulos acústicos e visuais na literatura, não foram encontrados trabalhos que utilizassem como estímulos trechos musicais, mas apenas estímulos sonoros simples como ruídos ou sinais. O mesmo ocorreu com os estímulos visuais utilizados nos experimentos (como, por exemplo, pontos) os quais não apresentavam características semânticas. Portanto, considerando as diferenças dos estímulos utilizados em trabalhos encontrados na literatura com os da atual pesquisa, que utilizará estímulos atribuídos de valor semântico (músicas clássicas e imagens de esculturas de bailarinas), foram realizadas aproximações relacionando as características perceptuais auditivas e visuais intrínsecas à observação dos estímulos mencionados.

Resumidamente, os trabalhos que analisaram a integração audiovisual (Jack \& Thurlow, 1973; Radeau \& Bertelson, 1977, 1978; Welch \& Warren, 1980; Howard \& Templeton, 1996; Spence \& Driver, 1996, 1997; Stein et al., 1998; Meyer \& Wuerger, 1998, 2001; Mcdonald et al., 2000; Bulking e Groh, 2006; Burr, Banks \& Morrone, 2009) indicam que a visão tende a dominar a audição em tarefas que demandem um processamento espacial (efeito ventríloquo). Entretanto, em tarefas que requerem processamento temporal a audição tende a se sobrepor à visão, tendência que tem sido denominada de Ventriloquismo temporal (Burr, Banks \& Morrone, 2009). Estas pesquisas indicam ainda que se o estímulo auditivo for consistente ao estímulo visual, ou seja, tiver a mesma velocidade e direção (Meyer \& Wuerger, 2001) o primeiro exercerá um domínio sobre o segundo. Provavelmente, este domínio possa existir em função da congruência ${ }^{18}$ entre os estímulos.

A generalização deste enunciado permite supor que a percepção de uma imagem estática de uma bailarina e uma música clássica, apresentadas simultaneamente, possa sofrer uma influência maior do estímulo acústico se o andamento musical for

\footnotetext{
${ }^{18}$ No estudo de Meyer e Wuerger a congruência é resultado da apresentação sincronizada dos pontos e dos ruídos (mesma velocidade e posição). Analogicamente, a apresentação de um passo de balé estático com uma música na qual este passo pode ser executado também seria um caso de congruência entre os estímulos.
} 
congruente com o passo representado na imagem. Provavelmente, apenas bailarinos consigam discernir entre o andamento adequado para o passo representado na imagem. O efeito da congruência entre estímulos acústicos e visuais poderia ser verificado em estimações temporais de indivíduos treinados e não treinados em dança? 


\section{Objetivos e Justificativas}

O artista impressionista Edgar Degas é mundialmente conhecido pela qualidade da representação de movimento de suas obras (Argan, 1995; Growe, 2001; Strickland, 2004). Nas suas esculturas em bronze de bailarinas, o artista retratou diferentes passos de Balé Clássico como, por exemplo, as posições Arabesques e Atitudes que são caracterizadas pela manutenção do equilíbrio corporal, mesmo com a elevação de uma das pernas (Bertoni, 1992; Bambirra, 1993; Caminada, 2001).

Braddick (1995), Cutting (2002) e Nather e Bueno (2006a), analisando a representação de movimento em obras de arte, verificaram que o movimento de corpos humanos em uma imagem bidimensional está relacionado à simetria da cabeça, tronco e membros. Provavelmente, um Arabesque representado nas bailarinas de Edgar Degas pode induzir à percepção de maior movimento, devido à colocação das pernas e quadris em relação aos ombros e braços (Nather \& Bueno, 2011).

A representação de movimento em imagens estáticas tem sido abordada sob o enfoque de movimentos irreversíveis (Freyd, 1983), de movimentos coerentes (Shiffar \& Freyd, 1993), de mecanismos de embodiment (Freedberg \& Gallese, 2007), de ativações neurais envolvidas na visualização de movimento estático (Kourtzi \& Kanwisher, 2000) e ainda sob o enfoque da percepção temporal (Nather \& Bueno, 2006b; Nather \& Bueno, 2011a,b). Para Freedberg e Gallesse (2007) as respostas físicas do observador localizam-se nas partes do corpo que estão sendo observadas, devido à ativação de um conjunto de neurônios que reconstroem a ação observada. Este conjunto de células neuronais é denominado neurônios espelho (revisão em Rizzolatti \& Graigheiro, 2004).

O uso de imagens em movimento de balé tem revelado um efeito do treinamento na ativação de áreas cerebrais relacionadas à percepção visual de movimento (Calvo-Marino et al., 2005; 2006; Cross et al., 2006). De acordo com estas pesquisas, indivíduos treinados em dança têm uma ativação cerebral maior ao observarem imagens de pessoas dançando do que indivíduos não treinados em dança. Nather, Bueno e Bigand (2009) verificaram diferenças na percepção temporal de indivíduos treinados e não treinados em Balé Clássico, utilizando imagens estáticas de bailarinas de Degas.

Nather e Bueno (2006a, b, 2008, 2011a, b) e Nather et al. (2011) vêm estudando os efeitos da representação de movimento das esculturas de Degas na 
percepção subjetiva de tempo. Nather e Bueno (2006b) verificaram que, quando duas imagens estáticas são apresentadas em uma tarefa de estimação temporal, quanto maior o movimento representado na imagem maior a estimação temporal dos participantes. Em um estudo posterior Nather e Bueno (2008; 2011b) desenvolveram uma escala de representação de movimento denominada de Body Moviment Ranking Scale (BMRS). Neste estudo foram utilizadas 16 imagens de esculturas de bailarinas do artista Edgar Degas em diferentes posições de Balé Clássico. Os participantes foram divididos em dois grupos, Treinados em dança e Não treinados em dança, e foram convidados a estimar temporalmente as imagens sob o paradigma prospectivo através do método de reprodução temporal. Os resultados das estimações temporais indicaram que pessoas treinadas em dança tenderam a subestimar as imagens, enquanto que pessoas não treinadas em dança realizaram superestimações. Os resultados da escala de movimento mostraram que as imagens de esculturas de bailarinas em diferentes posições de Arabesques foram agrupadas entre as maiores pontuações (5.0 e 6.0-pontos) tanto para o grupo de indivíduos treinados em dança quanto para o grupo de indivíduos não treinado. Este resultado sugere que as diferentes intensidades de movimento representado nas imagens são percebidas independentemente do treinamento em Balé.

A utilização de músicas clássicas em estudos de tempo subjetivo (Bueno, Firmino \& Engelman, 2002; Bueno \& Ramos, 2007; Bueno \& Cocenas, 2010) revelaram que os diferentes parâmetros musicais podem alterar a experiência temporal dos participantes. Músicas com maior quantidade de informação (como, por exemplo, constituídas de mais acordes por minuto) tendem a ser julgadas mais longas do que músicas mais simples.

Até o momento, não foram encontrados trabalhos que utilizassem simultaneamente obras de arte acústicas e visuais para verificar o efeito desta interação na estimação subjetiva de tempo. Entretanto, várias pesquisas verificaram como a interação som/imagem é percebida por humanos utilizando estímulos sem valor semântico (Jack \& Thurlow, 1973; Radeau \& Bertelson, 1977, 1978; Welch \& Warren, 1980; Howard \& Templeton, 1996; Spence \& Driver, 1996, 1997; Stein et al., 1998; Mcdonald et al., 2000; Bulking e Groh ,2006; Burr, Banks \& Morrone, 2009) como, por exemplo, flashes de luz e sons de bip (Sham et al., 2000) e pontos pretos em movimento e ruídos sonoros (Meyer \& Wuerger, 2001). Estes estudos indicaram que a visão tende a dominar a audição em tarefas que demandem um processamento espacial (efeito ventríloquo). Por outro lado, em tarefas que requerem processamento temporal a 
audição tende a se sobrepor à visão, tendência que tem sido denominada de ventriloquismo temporal (Burr, Banks \& Morrone, 2009). Estas pesquisas indicaram ainda que, se o estímulo auditivo for consistente ao estímulo visual, ou seja, se tiver a mesma velocidade e direção (Meyer \& Wuerger, 2001) o primeiro exercerá um domínio sobre o segundo. Provavelmente, este domínio possa existir em função da congruência entre os estímulos.

A arte da dança emerge da simultaneidade movimento/música, o tempo de cada movimentação corporal é baseado no andamento musical no qual o movimento está sendo realizado. Portanto, a apresentação de uma imagem estática de uma bailarina em posição de balé em conjunto com uma música clássica promoverá a junção das propriedades musicais (como, por exemplo, o andamento) com as propriedades visuais de esculturas de bailarinas (intensidade de representação de movimento). Qual seria o efeito da junção destes parâmetros na estimação subjetiva de tempo de participantes treinados e não treinados em dança?

\subsection{Objetivos Gerais}

O presente estudo tem como objetivos (1) verificar se trechos musicais e imagens estáticas com representação de movimento, conjuntamente, afetam a percepção subjetiva de tempo; (2) verificar se há diferença na estimação subjetiva de tempo destes estímulos audiovisuais entre pessoas treinadas e não treinadas em dança. Para tanto, foram apresentados dois estímulos visuais (imagens de esculturas de Edgar Degas com diferentes representações de movimento) e um trecho musical em dois distintos andamentos (lento e rápido). Foram realizados dois experimentos: Experimento I com participantes não treinados em dança e Experimento II com participantes treinados em dança. 


\section{Experimento I}

Objetivo específico: Verificar se trechos musicais em diferentes andamentos (rápido e lento) e imagens estáticas com distintas intensidades de representação de movimento, conjuntamente, afetam a percepção subjetiva de tempo.

\section{Método}

\section{Participantes}

Participaram do experimento 115 indivíduos não treinados em dança, entre 18 e 38 anos de idade, de ambos os sexos, que apresentavam visão normal ou corrigida para normal. O procedimento adotado no experimento foi aprovado pelo Comitê de Ética da Faculdade de Filosofia, Ciências e Letras de Ribeirão Preto da Universidade de São Paulo (USP). Os dados foram coletados entre os meses de junho e outubro de 2010.

\section{Equipamento e Material}

O experimento foi realizado na Biblioteca Central do Campus da USP de Ribeirão Preto. Foram utilizadas imagens (fotografias) de duas esculturas do artista impressionista Edgar Degas, uma com menor e outra com maior representação de movimento, de acordo com a Body Moviment Ranking Scale - BMRS (Nather e Bueno, 2008) pontuadas como 3.0-pontos e 6.0-pontos, respectivamente (ver Figura 3, p. 19). Foi utilizado ainda um trecho de 36 segundos de música clássica de aula de balé do compositor C. W. Gluck, em andamento rápido - Allegro (ALE) - e outro em andamento lento - Adágio (ADG), sendo este último o andamento original (Lacerda, 1967 e Bertoni, 1992). As imagens eram exibidas numa tela plana de 19" conectada a um Notebook e fones de ouvido acoplados ao computador para a escuta dos trechos musicais. O programa Wave Surfer fez o registro das estimações temporais. Um questionário para coleta de dados pessoais, profissionais, julgamentos verbais do tempo de duração dos estímulos e possíveis emoções e sentimentos despertados por eles foi preenchido pelo participante (Anexo II). 


\section{Procedimento}

O paradigma temporal utilizado no experimento foi o prospectivo (Zakay, 1990), no qual os participantes são informados que farão estimações temporais, por meio do método da reprodução.

O tempo total de apresentação dos estímulos foi de 36 segundos. Em virtude de terem sido usadas as fotografias das esculturas e trechos de música clássica, a abordagem utilizada neste experimento foi a sintética.

Todos os participantes foram posicionados de maneira a estarem com suas cabeças voltadas à região central da tela do Notebook numa distância fixa de $50 \mathrm{~cm}$ da tela, com a orientação de prestar atenção às apresentações de música/imagem.

Cada participante foi conduzido individualmente à sala e convidado a sentar na sua cadeira. Em seguida lhe foi apresentado o Termo de Consentimento Livre e Esclarecido e após a leitura e assinatura do termo pelo participante, foram explicadas verbalmente as tarefas que ele deveria realizar durante o experimento: "Você observará duas imagens diferentes: as fotografias de duas diferentes esculturas de bailarinas do artista impressionista Edgar Degas, que fazem parte do acervo do Museu de Arte de São Paulo (MASP) acompanhadas de trechos de música clássica. Após o término de cada imagem você reproduzirá quanto durou cada apresentação utilizando o teclado de computador à sua frente. A primeira exibição música/imagem será apenas um treino, para explicar como você deverá proceder para realizar este experimento".

Em seguida foi dito: "Você apertará a tecla marcada play (azul) e aparecerá a primeira apresentação músical imagem. Após algum tempo, a apresentação músical imagem finalizar-se-á automaticamente e a tela ficará em branco. Quando isso acontecer, você irá estimar o tempo que observou esta exibição de músical imagem apertando a tecla iniciar (verde). Então, quando você achar que o tempo que você estará deixando passar se igualou àquele que você ficou observando a imagem, você apertará a tecla finalizar (vermelha), concluindo a sua estimação temporal. Para as outras duas apresentações você irá repetir o mesmo procedimento. Procure apreciar as imagens e a música como se você estivesse numa exposição artística". Então, foi pedido ao participante que não fizesse qualquer tipo de contagem de tempo: "Procure não fazer qualquer contagem de tempo durante essas tarefas". Antes do começo das tarefas, possíveis dúvidas para a realização do experimento foram esclarecidas. 
Logo após o término das estimações temporais, o participante foi orientado a observar novamente cada apresentação música/imagem e a preencher as Escalas de Diferencial Semântico, do tipo Likert de sete pontos, para as categorias: agradabilidade, movimento, familiaridade, esforço físico e complexidade. Cada participante também respondeu a um questionário (referente a dados pessoais e às experiências artísticas do participante) sendo as respostas anotadas pelo experimentador no Caderno de Dados. Havia também um espaço para preenchimento de observações finais identificadas pelo experimentador, como dúvidas ou falhas durante a execução do experimento pelos participantes.

Os participantes que apresentaram erros procedimentais interromperam ou conversaram com o experimentador durante as estimações temporais foram descartados das análises.

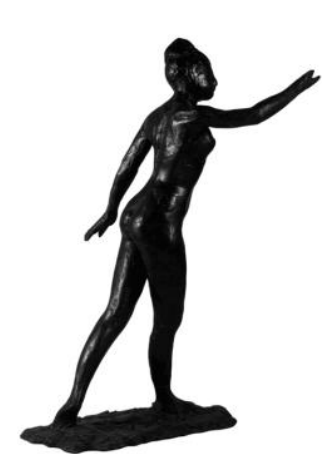

Estímulo Neutro

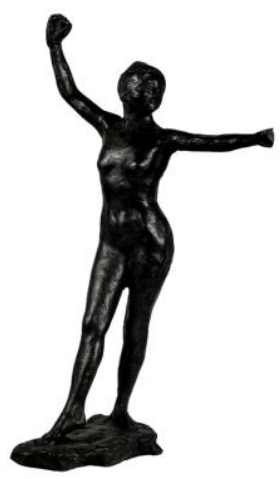

Estímulo 3.0

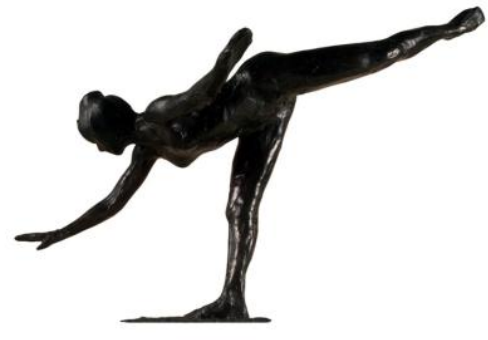

Estímulo 6.0

Figura 4. Estímulos que serão utilizados no Experimento. Estímulo Neutro: treino.

\subsection{Grupos Controle}

Para as variáveis música e imagem foram formados dois Grupos Controle: o Grupo Controle Imagem (GCI) e o Grupo Controle Música (GCM).

O método empregado em todos os grupos de estudo foi o mesmo. Entretanto, para os Grupos Controle alterou-se a informação de qual estímulo seria apresentado: 
música ou imagem. Assim onde se lê "apresentação música/imagem" (item 3. Procedimento, p.50) lê-se "apresentação da imagem" para o Grupo Controle Imagem e “apresentação de música” para o Grupo Controle Música. Ainda no grupo controle música, nas escalas de diferencial semântico, no lugar de "movimento" colocou-se velocidade e a categoria "esforço físico" foi excluída.

\subsubsection{Grupo Controle Imagem - GCI}

Participaram do Grupo Controle Imagem 32 indivíduos (19 homens) com idade média de 21,75 anos $( \pm 2,40)$. As imagens foram apresentadas em duas seqüências distintas:

Estímulo Treino

4.0

4.0
Estímulos

$6.0 \quad \Rightarrow \quad 3.0$

$3.0 \quad \Rightarrow \quad 6.0$
Indivíduos

15

17

\subsubsection{Grupo Controle Música - GCM}

Para o GCM foram apresentados os dois trechos da música clássica Idyll de C. W. Gluck em dois diferentes andamentos Allegro (ALE) - rápido e Adágio (ADG) lento, através de fones de ouvido acoplados ao notebook. Participaram do Grupo Controle Música 26 indivíduos (13 homens) com idade média de 22 anos $( \pm 3,06)$. As músicas foram apresentadas em duas sequências distintas:

\begin{tabular}{|c|c|c|c|c|c|}
\hline \multicolumn{2}{|c|}{ Estímulo Treino } & \multicolumn{3}{|c|}{ Estímulos } & Indivíd \\
\hline $\mathrm{N}$ & $\Rightarrow$ & $\mathrm{ADG}$ & $\Rightarrow$ & ALE & 14 \\
\hline $\mathrm{N}$ & $\Rightarrow$ & ALE & $\Rightarrow$ & $\mathrm{ADG}$ & 12 \\
\hline
\end{tabular}




\subsection{Grupo Experimental}

\subsubsection{Grupo Experimental Não Treinado - GNT}

Participaram do Grupo GNT 57 indivíduos (28 homens) com idade média de 22 anos $( \pm 3,41)$. As exibições de música/imagem para este grupo foram apresentadas nas seguintes seqüências:

Estímulo Treino

4.0/ADG

4.0/ ADG

4.0/ALE

4.0/ALE
Estímulos

6.0/ $\mathrm{ADG} \Rightarrow$

$3.0 / \mathrm{ADG} \quad \Rightarrow$

6.0/ $\mathrm{ALE} \quad \Rightarrow$

$3.0 / \mathrm{ADG}=>$
3.0/ ADG

6.0/ ADG

3.0/ ALE

6.0/ ALE
Indivíduos

14

15

13

15

Análise dos Dados

Os dados foram submetidos a testes de normalidade. Foram realizadas análises de variância ANOVA (One Way e Two Way) e testes $t$-Student. As análises ANOVA compararam os valores das estimações temporais entre os estímulos nas seqüências de apresentação e entre os grupos (One Way) e entre os grupos (Two Way). As análises $t$ Student foram utilizadas para a verificação das estimações temporais em relação ao tempo real de exposição dos estímulos.

Os dados das escalas de diferencial semântico foram submetidos a análises de variância ANOVA One Way nos grupos e Two Way entre os grupos. 


\section{Resultados}

\section{Grupo Controle Imagem - GCI}

Foram verificadas diferenças nos valores das estimações temporais dos estímulos nas sequências de apresentação: o tempo médio estimado para o estímulo 3.0pontos foi de $33,83 \mathrm{~s}$ e para o estímulo 6.0-pontos de $40,18 \mathrm{~s}$ quando apresentados como primeiros das séries. Estes valores foram estatisticamente diferentes quando os estímulos foram apresentados na segunda posição das sequências de apresentação $(36,55 \mathrm{~s}$ e $34,45 \mathrm{~s}$, respectivamente) $[\mathrm{F}(3,63)=2,899 ; \mathrm{p}<0,05]$. Tal resultado não permitiu agrupar os dados das sequiências experimentais. Desta forma, as próximas análises foram feitas considerando apenas as estimações médias dos primeiros estímulos de cada série.

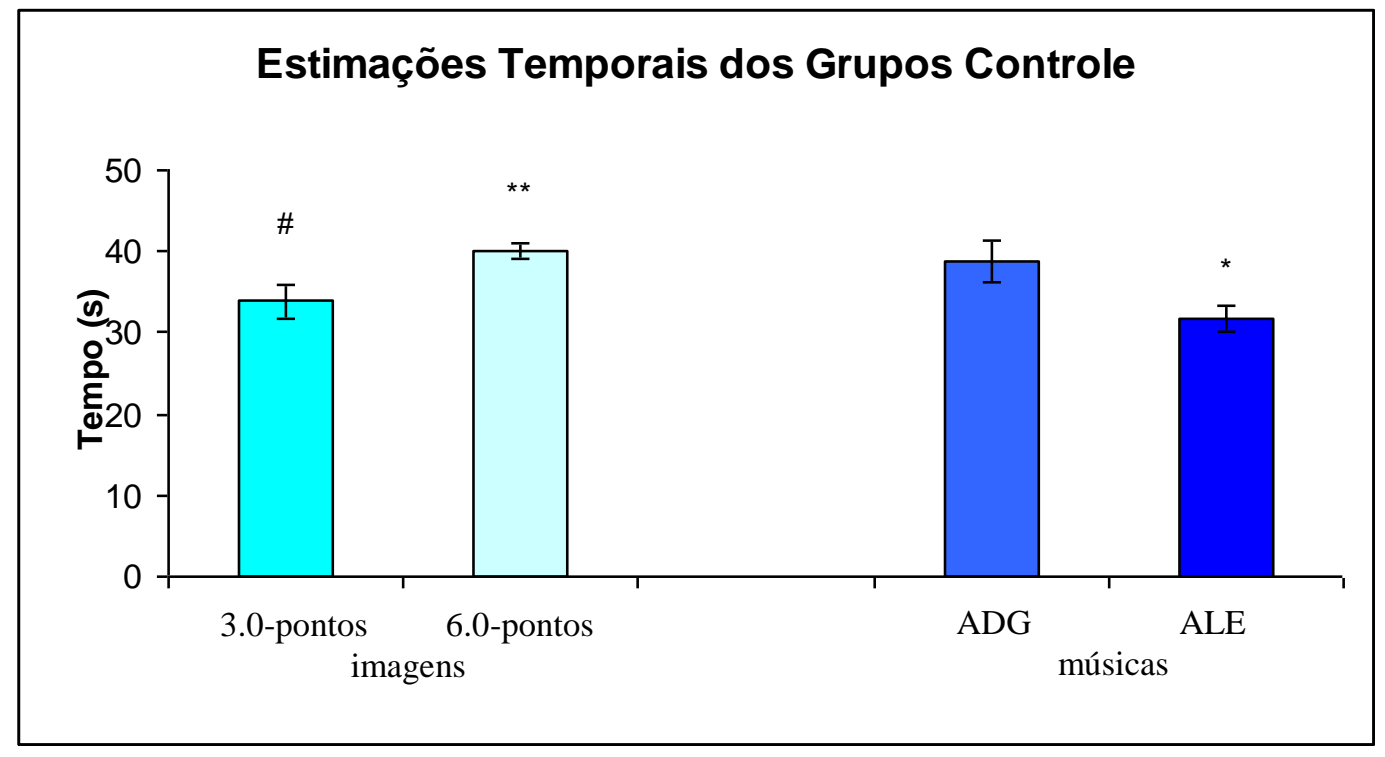

Figura 5: Estimações temporais dos Grupos controle GCI e GCM. Valores expressos em segundos. \# Indica que 3.0-pontos foi diferentemente estimado de 6.0-pontos [t(32) =-2, 689; p<0,05];

*Indica subestimação temporal do estímulo ALE em relação ao tempo real de exposição de 36 segundos $[\mathrm{t}(12)=-1,980 ; \mathrm{p}<0,05]$;

**Indica superestimação temporal do estímulo 6.0-point em relação ao tempo real de exposição de $36 \mathrm{~s}$ $[\mathrm{t}(15)=-4,458 ; \mathrm{p}<0,01])$. 
$\mathrm{Na}$ análise das estimações temporais médias dos primeiros estímulos da sequência experimental foi verificado que o Estímulo 3.0-pontos, com valor de 33,83 s, foi estatisticamente diferente do Estímulo 6.0-pontos com valor de 40,18s [t(32) =-2, 689; $\mathrm{p}<0,05]$ (Figura 5). A comparação das estimações médias dos estímulos com o tempo real de 36s mostrou que o estímulo 3.0-pontos foi estimado com duração semelhante ao tempo real $[\mathrm{t}(17)=0,915 ; \mathrm{p}>0,05]$, enquanto o estímulo 6.0-pontos foi superestimado $[\mathrm{t}(15)=-4,458 ; \mathrm{p}<0,01])$.

Na Tabela 1 estão mostrados os valores médios das pontuações das escalas de diferencial semântico do grupo GCI. As análises estatísticas destes valores para os critérios de representação de movimento [t(62)=3,411; $\mathrm{p}<0,01]$, de complexidade $[\mathrm{t}(62)=-8,578 ; \mathrm{p}<0,01]$ e de esforço físico $[\mathrm{t}(62)=8,248 ; \mathrm{p}<0,01]$ mostraram que para o estímulo 3.0-pontos os valores foram menores do que para o estímulo 6.0-pontos. As repostas às perguntas sobre os critérios de agradabilidade $[\mathrm{t}(62)=-0,903 ; \mathrm{p}>0,05] \mathrm{e}$ familiaridade $[t(62)=0,526 ; p>0,05])$ mostraram que os estímulos receberam pontuações não estatisticamente diferentes.

Tabela 1 - Valores médios das escalas de diferencial semântico e desvios-padrão (em parênteses) do Grupo Controle Imagem (GCI).

\begin{tabular}{lcc}
\hline \multicolumn{1}{c}{ Escalas } & Estímulo 3.0-point & Estímulo 6.0-point \\
\hline Agradabilidade & $4,68( \pm 1,38)$ & $5,00( \pm 1,44)$ \\
Movimento & $3,48( \pm 1,65)^{*}$ & $5,00( \pm 1,84)$ \\
Familiaridade & $4,26( \pm 1,79)$ & $4,00( \pm 2,07)$ \\
Esforço Físico & $2,71( \pm 1,74)^{*}$ & $6,06( \pm 1,31)$ \\
Complexidade & $2,52( \pm 1,43)^{*}$ & $5,61( \pm 1,52)$ \\
\hline
\end{tabular}

*Indica que os estímulos foram estatisticamente diferentes, sendo $6>3$ em movimento, esforço e complexidade. 


\section{Grupo Controle Música: GCM}

Não foram verificadas diferenças nos valores das estimações temporais dos estímulos nas seqüências de apresentação $[\mathrm{F}(3,51)=1,576 ; \mathrm{p}>0,05]$. As estimações médias de 38,74 s e $34,07 \mathrm{~s}$ do estímulo ADG e de 31,14 s e 38,78 s do estímulo ALE foram consideradas não estatisticamente diferentes. Entretanto, nas próximas análises foram considerados apenas os primeiros estímulos de cada série como no grupo GCI.

A análise das estimações temporais médias dos primeiros estímulos das séries mostrou que o Estímulo ADG, com estimação temporal média de 37,08s, não foi estatisticamente diferente do estímulo ALE, com estimação temporal média de 32,66s $[\mathrm{t}(26)=1,575 ; \mathrm{p}>0,05]$. O Estímulo ADG foi estimado com a mesma duração do tempo real de $36 \mathrm{~s}$ de exposição [t(14)=1,053; $\mathrm{p}>0,05]$, enquanto que o Estímulo ALE foi subestimado [t(12)=-1,980; $\mathrm{p}<0,05]$ (Figura 5).

Na Tabela 2 estão mostrados os dados das pontuações médias das escalas de diferencial semântico do grupo GCM. As análises estatísticas destes valores mostraram que para o critério de velocidade $[\mathrm{t}(52)=5,242 ; \mathrm{p}<0,01]$ o estímulo ALE foi julgado mais veloz que o estímulo ADG. Os critérios de agradabilidade [t(52)=-0,315; p>0,05], de familiaridade $[\mathrm{t}(52)=1,095 ; \mathrm{p}>0,05]$ e de complexidade $[\mathrm{t}(52)=-1,573 ; \mathrm{p}>0,05])$ receberam pontuações não estatisticamente diferentes.

Tabela 2 - Valores médios das escalas de diferencial semântico e desvios-padrão (em parênteses) do Grupo Controle Música (GCM).

\begin{tabular}{ccc}
\hline Escalas & Estímulo ALE & Estímulo ADG \\
\hline Agradabilidade & $5,22( \pm 1,25)$ & $5,11( \pm 1,34)$ \\
Velocidade & $4,07( \pm 1,30) \#$ & $2,37( \pm 1,08)$ \\
Familiaridade & $4,56( \pm 2,04)$ & $3,96( \pm 1,93)$ \\
Complexidade & $3,56( \pm 1,37)$ & $2,96( \pm 1,40)$ \\
\hline
\end{tabular}

\# Indica que o Estímulo ALE foi julgado mais veloz do que o Estímulo ADG. 


\section{Grupo Música/Imagem Não Treinados - GNT}

Foram verificadas diferenças nas estimações temporais para o estímulo ALE 3.0 na primeira posição $(28,36 \mathrm{~s})$ e na segunda posição $(38,10 \mathrm{~s}) \quad[\mathrm{F}(3,55)=4,047$; p<0,05]. Os estímulos ADG 3.0 (33,56s e 35,32s), ADG 6.0 (38,06s e 38,06s) e ALE $6.0(37,41 \mathrm{~s}$ e $31,10 \mathrm{~s})$ não apresentaram diferenças estatísticas significativas nas diferentes ordens de apresentação $[F(3,55)=1,050 ; p>0,05]$. Em vitude das diferentes estimações do estímulo ALE 3.0, foram utilizados nas análises posteriores apenas os dados dos primeiros estímulos de cada série.

Na Figura 6 estão representados os valores médios das reproduções temporais dos participantes do Grupo Experimental Não Treinado (GNT). A análise das estimações temporais médias do grupo GNT mostrou que não houve efeito da música nas estimações $[F(1,55)=1,794 ; p>0,05]$, mas houve efeito das imagens $[F(1,55)=9,612$; $\mathrm{p}<0,01]$. A análise também revelou que não houve interação música/imagem $[\mathrm{F}(1,55)=1,084 ; \mathrm{p}>0,05]$.

Os estímulos ADG 3.0 (33,56 s), ADG 6.0 (38,06s) e ALE $6.0(37,41 \mathrm{~s})$, receberam estimações não estatisticamente diferentes ao tempo real de $36 \mathrm{~s}$ (respectivamente, [t(14)=-1,091; $\mathrm{p}>0,05]),[\mathrm{t}(14)=-1,266 ; \mathrm{p}>0,05]$ e $[\mathrm{t}(15)=-0,895$; $\mathrm{p}>0,05])$. Por outro lado, a média das estimações temporais do estímulo ALE 3.0 $(28,36 \mathrm{~s})$ foi estatisticamente diferente do tempo real, sendo o estímulo subestimado $[\mathrm{t}(13)=2,698 ; \mathrm{p}<0,05]$.

Resumidamente, a análise do grupo GNT revelou que os indivíduos não treinados subestimaram o estímulo ALE 3.0 enquanto que os demais estímulos (ALE 6.0, ADG 3.0 e ADG 6.0) foram estimados com a mesma duração do tempo real. Para este grupo prevaleceram as diferenças entre as imagens: o estímulo com mais movimento foi julgado com maior duração que o estímulo com menor movimento, em detrimento da interação música/imagem. 


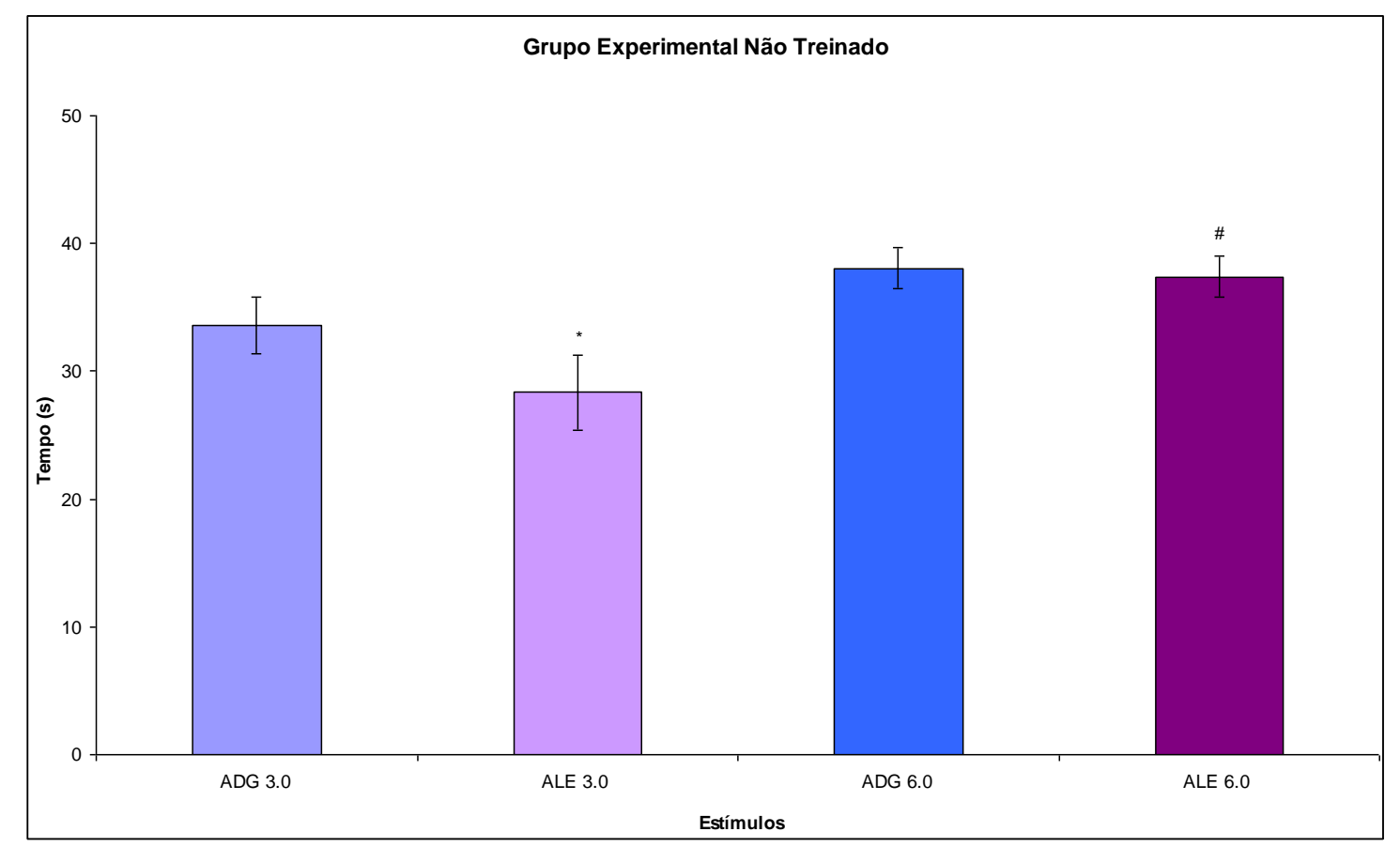

Figura 6: Estimações Temporais médias do Grupo Experimental GNT. * Indica subestimação temporal do estímulo ALE $3.0[\mathrm{t}(13)=2,698 ; \mathrm{p}<0,05]$; \# Indica que o estímulo ALE $3.0 \neq$ ALE 6.0 [t(28)=-2,741; $\mathrm{p}<0,05])$.

Na Tabela 3 estão mostradas as pontuações médias das escalas de diferencial semântico do grupo GNT. As análises estatísticas destes valores mostraram que nas respostas ao critério de complexidade não houve efeito da música $\mathrm{F}(1,125)=0,225$; $\mathrm{p}>0,05]$, mas houve efeito de imagem $[\mathrm{F}(1,125)=183,117 ; \mathrm{p}<0,05]$ e da interação música/imagem $[\mathrm{F}(1,125)=183,117 ; \mathrm{p}<0,05]$. As respostas para o critério de movimento não foram estatisticamente diferentes, não houve efeito da música $F(1,125)=1,091$; $\mathrm{p}>0,05]$, mas efeito das imagens $[\mathrm{F}(1,125)=50,960 ; \mathrm{p}<0,01]$ e da interação música/imagem $[\mathrm{F}(1,125)=5,191 ; \mathrm{p}<0,05]$.

Para o critério esforço físico as análises mostraram um efeito das imagens nas estimações temporais $[\mathrm{F}(1,125)=199,859$; $\mathrm{p}<0,05]$, mas não houve efeito das músicas $[\mathrm{F}(1,125)=0,057 ; \mathrm{p}>0,05]$ e da interação música/imagem $[\mathrm{F}(1,125)=1,549 ; \mathrm{p}>0,05]$. Para os critérios familiaridade $[\mathrm{F}(1,125)=0,523 ; \mathrm{p}>0,05] ;[\mathrm{F}(1,125)=3,805 ; \mathrm{p}>0,05]$; $[F(1,125)=0,082 ; p>0,05$ e agradabilidade $[F(1,125)=0,310 ; p>0,05] ;[F(1,125)=0,071$; $\mathrm{p}>0,05]$ e $[\mathrm{F}(1,125)=0,156 ; \mathrm{p}>0,05])$ não houve efeito de música, de imagens ou de interação música/imagem em todos os estímulos. Portanto, o resultado da análise das pontuações médias das escalas de diferencial semântico do grupo GNT indicou efeito 
das imagens e da interação música/imagem para os critérios complexidade e movimento. Para o critério esforço físico houve um efeito apenas entre as imagens. Para os critérios de agradabilidade e familiaridade todos os estímulos não foram estatisticamente diferentes.

Tabela 3 - Valores médios das escalas de diferencial semântico e desvios-padrão (em parênteses) do Grupo Experimental Não Treinado (GNT) para os estímulos ADG 3.0, ALE 3.0, ADG 6.0 e ALE 6.0.

\begin{tabular}{lcccc}
\hline \multicolumn{1}{c}{ Escalas } & ADG 3.0 & ALE 3.0 & ADG 6.0 & ALE 6.0 \\
\hline Agradabilidade & $5,19( \pm 1,33)$ & $5,42( \pm 1,29)$ & $5,22( \pm 1,45)$ & $5,26( \pm 1,39)$ \\
Movimento* & $3,03( \pm 1,45)$ & $3,94( \pm 1,41)$ & $5,59( \pm 1,81)$ & $5,74( \pm 1,26)$ \\
Familiaridade & $5,06( \pm 1,81)$ & $4,71( \pm 1,88)$ & $4,28( \pm 2,19)$ & $4,13( \pm 1,93)$ \\
Esforço Físico\# & $2,94( \pm 1,63)$ & $3,29( \pm 1,83)$ & $6,59( \pm 1,63)$ & $6,35( \pm 0,88)$ \\
Complexidade* & $2,59( \pm 1,46)$ & $3,19( \pm 1,54)$ & $6,22( \pm 0,49)$ & $5,84( \pm 1,21)$ \\
\hline
\end{tabular}

* Indica diferenças estatísticas entre imagens e de interação música/imagem;

\# Indica diferença estatística apenas entre as imagens.

\section{Discussão}

A análise dos dados das estimações temporais dos Grupos Controle Imagem e Música (GCI e GCM) sugere que, separadamente, tanto a imagem quanto o andamento musical podem alterar a experiência temporal dos participantes: quanto mais movimento representado maior a estimação temporal e quanto mais rápido o ritmo musical menor o tempo estimado.

A análise dos valores médios das estimações do grupo GCI mostrou que a imagem com maior sugestão de movimento (bailarina em posição de Penché; 6.0pontos) alterou a percepção subjetiva de tempo dos participantes: tal imagem foi superestimada em relação ao tempo real de apresentação. Por outro lado, a imagem com menor representação de movimento (Prelúdio para a dança; 3.0-pontos) foi estimada 
com duração não estatisticamente diferente do tempo real de apresentação. Estes dados corroboram com dados de pesquisas anteriores (Nather \& Bueno 2006a, 2008, 2011a, b; Nather, Bueno \& Bigand 2009) os quais sugerem que quanto maior a intensidade de representação de movimento numa imagem estática maior será sua estimação temporal.

No Grupo Controle Música (GCM), o resultado das estimações temporais médias revelou que o estímulo Allegro (de andamento mais rápido) encurtou a experiência temporal dos participantes e foi subestimado em relação ao tempo real de apresentação. Por outro lado, o estímulo Adágio foi estimado com a mesma duração do tempo real de apresentação. Estes resultados não corroboram com trabalhos de tempo subjetivo que utilizaram músicas clássicas como estímulos (Bueno, Firmino \& Engelman, 2002; Bueno \& Ramos, 2007; Bueno \& Cocenas, 2010). Entretanto, estes estudos utilizaram músicas diferentes com distintos andamentos e, no presente estudo, foi utilizado um trecho comum de música clássica em dois andamentos diferentes.

Segundo Ornstein (1969), quanto maior a quantidade de informação num determinado estímulo maior será sua estimação temporal de um evento. Pode-se supor que o estímulo Allegro, por ter um andamento mais rápido e possuir mais compassos (portanto mais informação) seria estimado como mais longo do que o estímulo Adágio, de andamento mais lento. Entretanto, este resultado não foi verificado nas análises do presente estudo. Por outro lado, diferenças nas estimações temporais entre músicas de andamento rápido e lento, mostraram que as músicas de andamento lento levam a maiores imprecisões temporais (North, Hargreaves e Heath, 1998). Outros estudos que compararam diferentes métodos de estimação temporal mostraram não haver concordância nos resultados das estimções temporais mesmo utilizando estímulos idênticos (Brown, 1985; Block, 1990; Graf e Grondin, 2006).

As análises do Grupo Experimental Não Treinado (GNT) mostraram duas possibilidades de explicação dos efeitos da interação música/imagem. Considerando as análises envolvendo as comparações entre estímulos o efeito da imagem sobrepujou o efeito das músicas: a interação música/imagem entre os estímulos indicou efeito das imagens nas estimações temporais, não havendo efeito de música ou da interação música/imagem.

Por outro lado, considerando as análises comparando os estímulos com o tempo real de exposição dos mesmos foi também verificado um efeito das músicas sobre as imagens. Em relação ao tempo real de exposição de 36s, foi verificado um efeito da música em andamento mais lento (Adágio). Em relação à apresentação das 
imagens com a música em andamento lento, as imagens foram estimadas com duração não estatisticamente diferente do tempo real de apresentação; em relação ao grupo controle a imagem 6.0-pontos também sofreu alteração para menos. Neste grupo, a percepção temporal dos indivíduos em relação à representação de movimento foi mais alterada quando os estímulos foram apresentados em conjunto com a música ADG. Assim, os estímulos 3.0- e 6.0-pontos foram estimados com a mesma duração que o tempo real. Este resultado indica que a música em andamento lento teve um efeito sobre o movimento representado nas imagens. A música Allegro também exerceu uma influência sobre as imagens que foram estimadas com menor duração em relação ao grupo controle: o estímulo ALE 3.0 foi subestimado enquanto que o estímulo ALE 6.0 foi estimado com a mesma duração do tempo real. Mas, mesmo com a alteração para menos em relação ao grupo GCI, as estimações temporais das imagens continuaram apresentando diferenças significativas entre si, o estímulo 3.0-pontos foi estimado com menor duração que 6.0-pontos.

Provavelmente, mesmo havendo uma influência do estímulo acústico, a intensidade de representação de movimento das imagens continua exercendo um efeito sobre a estimação subjetiva de tempo de pessoas leigas em dança, quando a música utilizada está em andamento rápido. Pode-se inferir que há um efeito do andamento de uma mesma música em Adágio ou Allegro nas estimações temporais de imagens estáticas com diferentes representações de passos de balé.

Distintos trabalhos sobre interação de estímulos acústicos e visuais mostraram que há um efeito do estímulo auditivo sobre o estímulo visual (Sekuler \& Sekuler, 1999; Shams et al., 2000, 2001; Meyer \& Wuerger, 2001; Berger et al., 2003; Burr, Banks \& Marrone, 2009). Burr, Banks e Morrone (2009) utilizaram estímulos acústicos e visuais e verificaram que o som tende a dominar a percepção temporal de estímulos audiovisuais. Apesar de haver uma prevalência do estímulo auditivo em tarefas de estimação temporal, os autores indicam que pode haver oscilações neste domínio. Assim, existe uma possibilidade do domínio não ser total, dependendo do indivíduo ou do estímulo apresentado os resultados podem ser divergentes. Isto explicaria porque o tanto a música em andamento Allegro quanto em Adágio exercem um efeito diferente sobre as imagens. Por exemplo, músicas em Allegro são vívidas, alegres (agitadas) e podem ser consideradas incongruentes em relação às imagens estáticas.

Meyer e Wuerger (2001) verificaram que a combinação da velocidade e da direção do estimulo auditivo e visual promove um viés na resposta visual influenciada 
pelo estímulo auditivo, ou seja, quando os estímulos auditivos e visuais são congruentes há uma tendência de predomínio auditivo. Dessa forma, pode-se inferir que a música em andamento lento exerceu maior influencia sobre estímulos visuais do que a música em andamento rápido, porque músicas em andamento lento seriam mais congruentes com imagens estáticas de bailarinas em diferentes passos de balé para pessoas não treinadas em dança.

As informações obtidas com a análise dos relatos verbais revelaram que os participantes tenderam a utilizar a informação auditiva sobre o visual nas estratégias de estimação temporal. Quando perguntados sobre como estimaram o tempo, 51,08\% dos participantes disseram que se embasaram na música e apenas $23,20 \%$ disseram atentar para a imagem. Ambas as informações (música imagem) foram utilizadas por 10,07\% dos indivíduos enquanto 12,05\% relataram não fazer nada. Enquanto estratégia, a música predominou sobre a imagem durante a tarefa de estimação temporal dos participantes.

As análises das escalas de diferencial semântico do Grupo Controle Imagem (GCI) revelaram que as imagens 3.0-pontos e 6.0-pontos foram julgadas diferentes para os critérios de movimento, esforço e complexidade. No Grupo Controle Música (GCM) os estímulos Adágio (ADG) e Allegro (ALE) foram julgados diferentes apenas para o critério velocidade. Quando os estímulos foram apresentados simultaneamente, no Grupo Experimental Não Treinado (GNT), os estímulos foram julgados diferentes em relação aos critérios movimento, complexidade e esforço físico. Para os critérios de movimento e complexidade, houve um efeito das imagens e da interação som/imagem, por outro lado, para o critério esforço físico houve apenas um efeito das imagens. Estes resultados também indicam um efeito das diferentes intensidades de movimento representado nas imagens, que se distinguiram tanto nos julgamentos das escalas quanto nas estimações temporais. $\mathrm{O}$ resultado da escala de diferencial semântico para o critério velocidade mostrou que o estímulo Allegro foi julgado mais veloz do que o estímulo Adágio (de andamento lento).

Os resultados das escalas de diferencial semântico dos grupos controle e do grupo experimental confirmaram o efeito dos diferentes movimentos representados nas imagens, assim como o efeito do andamento musical na percepção dos participantes Portanto, pode-se inferir que o efeito das imagens nas estimações temporais entre os estímulos deve-se aos distintos passos de Balé representados nas imagens. E, por outro 
lado, o efeito das músicas nas estimações temporais dos estímulos, em relação ao tempo real de apresentação, deve-se aos distintos andamentos musicais apresentados. 


\section{Experimento II}

Objetivo específico: Verificar o efeito do treinamento em dança na percepção subjetiva de tempo de estímulos acústicos (trechos de música clássica em diferentes andamentos) e estímulos visuais (imagens de esculturas de bailarinas em diferentes posições) apresentados simultaneamente.

\section{Método}

\section{Participantes}

Participaram do experimento 49 indivíduos treinados em dança, entre 18 e 38 anos de idade, de ambos os sexos, que apresentavam visão normal ou corrigida para normal. O procedimento adotado no experimento foi aprovado pelo Comitê de Ética da Faculdade de Filosofia, Ciências e Letras de Ribeirão Preto da Universidade de São Paulo (USP). Os dados foram coletados entre os meses de junho e outubro de 2010.

\section{Equipamento e material}

O experimento foi realizado na Biblioteca Central do Campus da USP de Ribeirão Preto. Foram utilizadas imagens (fotografias) de duas esculturas do artista impressionista Edgar Degas, uma com menor e outra com maior representação de movimento, de acordo com a Body Moviment Ranking Scale - BMRS (Nather e Bueno, 2008) pontuadas como 3.0-pontos e 6.0-pontos, respectivamente (ver Figura 3, p. 19). Foi utilizado ainda um trecho de 36 segundos de música clássica de aula de balé do compositor C. W. Gluck, em andamento rápido - Allegro (ALE) - e outro em andamento lento - Adágio (ADG), sendo este último o andamento original (Lacerda, 1967 e Bertoni, 1992). As imagens eram exibidas numa tela plana de 19" conectada a um Notebook e fones de ouvido acoplados ao computador para a escuta dos trechos musicais. O programa Wave Surfer fez o registro das estimações temporais. Um questionário para coleta de dados pessoais, profissionais, julgamentos verbais do tempo de duração dos estímulos e possíveis emoções e sentimentos despertados por eles foi preenchido pelo participante (Anexo II). 


\section{Procedimento}

O paradigma temporal utilizado no experimento foi o prospectivo (Zakay, 1990), no qual os participantes são informados que farão estimações temporais, por meio do método da reprodução.

O tempo total de apresentação dos estímulos foi de 36 segundos. Em virtude de terem sido usadas as fotografias das esculturas e trechos de música clássica, a abordagem utilizada neste experimento foi a sintética.

Todos os participantes foram posicionados de maneira a estarem com suas cabeças voltadas à região central da tela do Notebook numa distância fixa de $50 \mathrm{~cm}$ da tela, com a orientação de prestar atenção às apresentações de música/imagem.

Cada participante foi conduzido individualmente à sala e convidado a sentar na sua cadeira. Em seguida lhe foi apresentado o Termo de Consentimento Livre e Esclarecido e após a leitura e assinatura do termo pelo participante, foram explicadas verbalmente as tarefas que ele deveria realizar durante o experimento: "Você observará duas imagens diferentes: as fotografias de duas diferentes esculturas de bailarinas do artista impressionista Edgar Degas, que fazem parte do acervo do Museu de Arte de São Paulo (MASP) acompanhadas de trechos de música clássica. Após o término de cada imagem você reproduzirá quanto durou cada apresentação utilizando o teclado de computador à sua frente. A primeira exibição música/imagem será apenas um treino, para explicar como você deverá proceder para realizar este experimento".

Em seguida foi dito: "Você apertará a tecla marcada play (azul) e aparecerá a primeira apresentação música/ imagem. Após algum tempo, a apresentação música/ imagem finalizar-se-á automaticamente e a tela ficará em branco. Quando isso acontecer, você irá estimar o tempo que observou esta exibição de música/ imagem apertando a tecla iniciar (verde). Então, quando você achar que o tempo que você estará deixando passar se igualou àquele que você ficou observando a imagem, você apertará a tecla finalizar (vermelha), concluindo a sua estimação temporal. Para as outras duas apresentações você irá repetir o mesmo procedimento. Procure apreciar as imagens e a música como se você estivesse numa exposição artística". Então, foi pedido ao participante que não fizesse qualquer tipo de contagem de tempo: "Procure não fazer qualquer contagem de tempo durante essas tarefas". Antes do começo das tarefas, possíveis dúvidas para a realização do experimento foram esclarecidas. 
Grupo Treinado - GT

Participaram do Grupo GT 49 indivíduos (12 homens) com idade média de 24 anos $( \pm 4,24)$ e com tempo médio de treinamento em balé de 10,87 anos $( \pm 5,24)$. As exibições de música/imagem foram apresentadas nas seguintes seqüências:

Estímulo Treino

$$
\text { 4.0/ADG }
$$

4.0/ADG

4.0/ALE

4.0/ALE
Estímulos

6.0/ $\mathrm{ADG} \quad \Rightarrow$

$3.0 / \mathrm{ADG} \quad \Rightarrow$

$6.0 / \mathrm{ALE} \quad \Rightarrow$

$3.0 / \mathrm{ADG}=>$
3.0/ ADG

6.0/ ADG

3.0/ ALE

6.0/ ALE
Indivíduos

13

12

12

12

Análise dos Dados

Os dados foram submetidos a testes de normalidade. Foram realizadas análises de variância ANOVA (One Way e Two Way) e testes $t$-Student. As análises ANOVA compararam os valores das estimações temporais entre os estímulos nas sequências de apresentação e entre os grupos (One Way) e entre os grupos (Two Way) e . As análises t- Student foram utilizadas para a verificação das estimações temporais em relação ao tempo real de exposição dos estímulos.

Os dados das escalas de diferencial semântico foram submetidos a análises de variancia ANOVA One Way nos grupos e Two Way entre os grupos. 


\section{Resultados}

\section{Grupo Experimental Treinado - GT}

Foram verificadas diferenças nas estimações temporais na ordem de apresentação das imagens nas seqüências apenas para o estímulo ADG 6.0, entre a primeira $(37,90 \mathrm{~s})$ e a segunda $(32,17 \mathrm{~s})$ posição $[\mathrm{F}(3,57)=3,567 ; \mathrm{p}<0,05]$. Os estímulos ALE $3.0(35,81 \mathrm{~s}$ e 36,12s), ALE $6.0(37,22 \mathrm{~s}$ e 35,98s) e ADG $3.0(31,95 \mathrm{~s}$ e 37,18s) não apresentaram diferenças estatísticas significativas $[F(3,51)=0,187 ; p>0,05]$. Em virtude das diferentes estimações do estímulo ADG 6.0, foram utilizados nas análises posteriores apenas os dados dos primeiros estímulos de cada série.

Na Figura 7 estão representados os valores médios das estimações temporais dos participantes do grupo GT. A análise das estimações temporais médias mostrou que não houve efeito da música dos diferentes estímulos $[\mathrm{F}(1,48)=0,424 ; \mathrm{p}>0,05]$, mas houve efeito das imagens $[\mathrm{F}(1,48)=6,302 ; \mathrm{p}<0,05]$. A análise também revelou que não houve efeito da interação música/imagem $[\mathrm{F}(1,48)=2,777 ; \mathrm{p}>0,05]$.

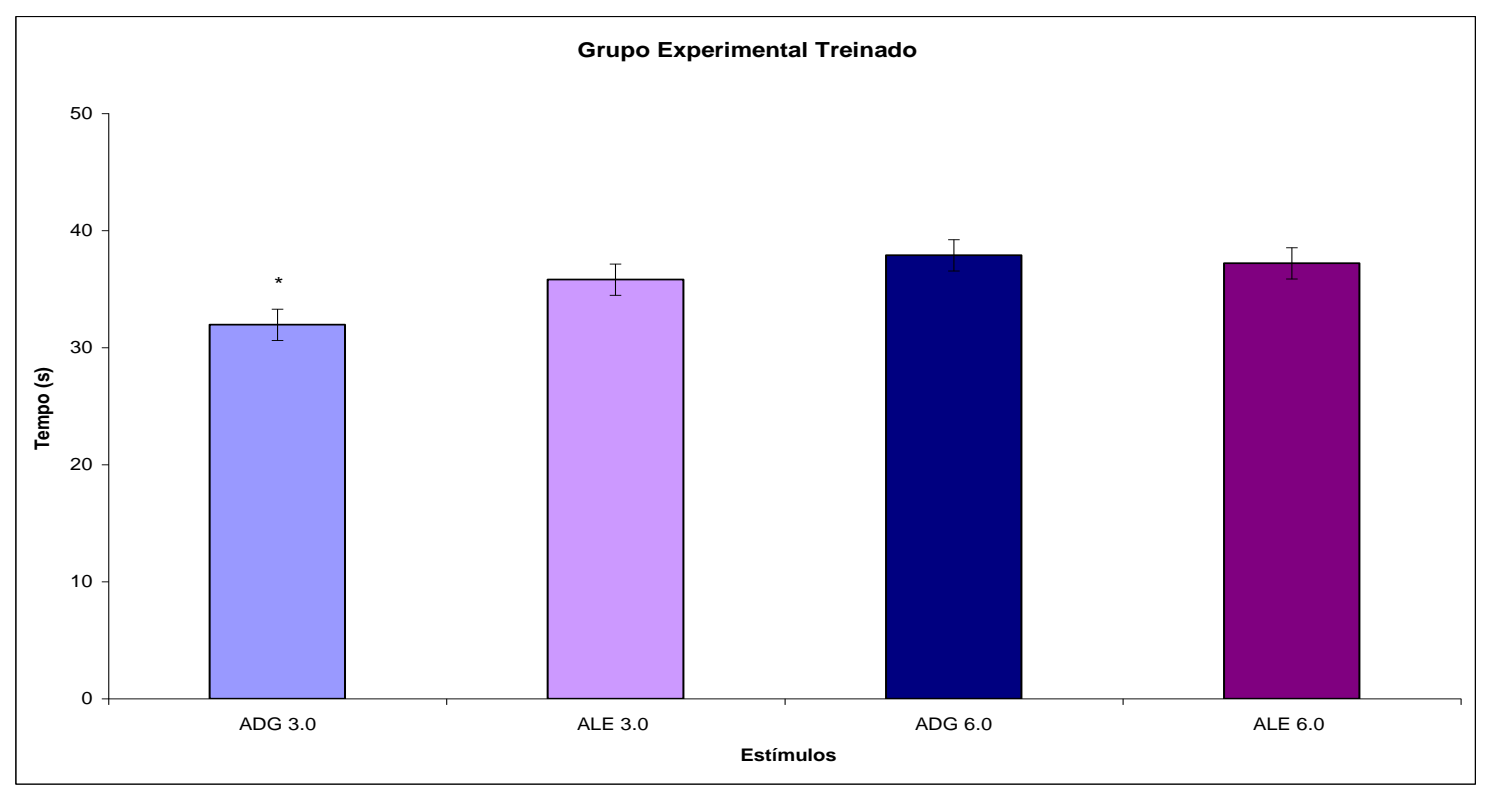

Figura 7 - Valores médios das estimações temporais e erros padrão dos Estímulos ADG 3.0, ALE 3.0, ADG 6.0 e ALE 6.0 do Grupo Experimental GT. Valores expressos em segundos.* Indica subestimação temporal em relação aos 36s de apresentação. 
Os valores médios das estimações dos estímulos ADG 6.0 (37,90 s), ALE 3.0 $(35,81 \mathrm{~s})$ e ALE 6.0 (37,22 s) não foram estatisticamente diferentes quando comparados ao tempo real de 36s de exposição (respectivamente, [t(12)=-2,908; p>0,05]), $[\mathrm{t}(12)=0,195 ; \mathrm{p}>0,05]$ e $[\mathrm{t}(12)=-0,776 ; \mathrm{p}>0,05])$. Por outro lado, a média das estimações temporais do estímulo ADG 3.0 (31,95 s) foi estatisticamente diferente do tempo real, sendo o estímulo subestimado [ $\mathrm{t}(13)=2,096 ; \mathrm{p}<0,05]$. Ou seja, no Grupo GT o estímulo ADG 3.0 foi subestimado, enquanto os demais estímulos (ADG 6.0, ALE 3.0 e ALE 6.0) foram estimados com a mesma duração do tempo real.

$\mathrm{Na}$ Tabela 4 estão mostradas as pontuações médias das escalas de diferencial semântico do grupo GT. As análises estatísticas destes valores mostraram que em relação aos critérios complexidade houve efeito da imagem $[\mathrm{F}(1,105)=106,249$; $\mathrm{p}<0,05]$, mas não houve efeito da música $[\mathrm{F}(1,105)=0,185 ; \mathrm{p}>0,05]$ ou da interação música/imagem $[\mathrm{F}(1,105)=0,214 ; \mathrm{p}>0,05]$. Resultado semelhante foi encontrado na análise das pontuações médias para o critério esforço físico $[\mathrm{F}(1,105)=15,935 ; \mathrm{p}<0,05]$, $[F(1,105)=0,184 ; p>0,05]$ e $[F(1,105)=0,792 ; p>0,05]$.

Tabela 4 - Valores médios das escalas de diferencial semântico e desvios-padrão (em parênteses) do Grupo Experimental Treinado (GT) para os estímulos ADG 3.0, ALE 3.0, ADG 6.0 e ALE 6.0.

\begin{tabular}{lcccc}
\hline \multicolumn{1}{c}{ Escalas } & ADG 3.0 & ALE 3.0 & ADG 6.0 & ALE 6.0 \\
\hline Agradabilidade & $5,17( \pm 1,43)$ & $5,16( \pm 1,40)$ & $5,33( \pm 1,58)$ & $5,24( \pm 1,62)$ \\
Movimento\# & $2,79( \pm 1,35)$ & $3,86( \pm 1,51)$ & $4,25( \pm 2,03)$ & $5,03( \pm 1,80)$ \\
Familiaridade & $6,71( \pm 0,62)$ & $6,76( \pm 0,44)$ & $6,25( \pm 0,85)$ & $6,38( \pm 1,35)$ \\
Esforço Físico* & $3,96( \pm 1,44)$ & $4,14( \pm 1,27)$ & $6,58( \pm 0,88)$ & $6,62( \pm 0,86)$ \\
Complexidade* $^{3,46( \pm 1,74)}$ & $3,69( \pm 1,44)$ & $6,25( \pm 0,99)$ & $6,24( \pm 1,02)$ \\
\hline
\end{tabular}

* Indica diferenças estatísticas significativas apenas entre as imagens;

\# Indica diferenças estatísticas significativas entre as imagens e entre as músicas. 
Para o critério movimento as análises mostraram diferenças estatísticas significativas entre as imagens $[\mathrm{F}(1,105)=102,140 ; \mathrm{p}<0,01]$ e entre as músicas $[F(1,105)=7,922 ; p<0,01]$. Para os critérios de familiaridade $([F(1,105)=0,294 ; p>0,05]$ e de agradabilidade $[\mathrm{F}(1,105)=0,970 ; \mathrm{p}>0,05]$ não houve diferenças estatísticas significativas entre as pontuações dos estímulos entre as imagens, entre as músicas ou na interação música/imagem.

As análises das escalas de diferencial semântico do grupo GT mostraram que os estímulos foram julgados com pontuações de complexidade e esforço físico diferentes apenas com relação às imagens. Em relação ao critério de movimento os estímulos foram julgados diferentes com relação às imagens e às músicas. Os estímulos foram considerados não estatisticamente diferentes para os critérios de familiaridade e agradabilidade.

2. Grupo Não Treinado (GNT) e Grupo Treinado (GT).

A análise das estimações temporais médias comparando os grupos GNT e GT mostrou que não houve diferença entre os grupos $[F(1,104)=1,186 ; p>0,05]$.

Em ambos os grupos foi verificado efeito das imagens $[\mathrm{F}(1,104)=14,876$; $\mathrm{p}<0,05]$. Entretanto, o efeito das imagens não foi diferente entre os grupos $[F(1,104)=0,724 ; p>0,05]$.

Tabela 5 - Valores médios das estimações temporais e desvios-padrão (em parênteses) dos Estímulos ADG 3.0, ALE 3.0, ADG 6.0 e ALE 6.0 dos Grupos Experimentais GNT e GT. Valores expressos em segundos.

\begin{tabular}{ccc}
\hline Estímulos & GNT & GT \\
\hline ADG 3.0 & $33,56( \pm 8,65)$ & $31,95( \pm 6,90)^{*}$ \\
ALE 3.0 & $28,36( \pm 10,00)^{*}$ & $35,81( \pm 3,46)$ \\
ADG 6.0 & $38,06( \pm 6,3)$ & $37,90( \pm 6,80)$ \\
ALE 6.0 & $37,41( \pm 6,10) \#$ & $37,22( \pm 5,66)$ \\
\hline & & \\
* Indica subestimação temporal em relação aos 36s de apresentação. \\
\# Indica que o estímulo ALE 6.0 foi estatisticamente diferente do estímulo ALE 3.0.
\end{tabular}


As comparações das médias das escalas de diferencial semântico para o critério agradabilidade mostraram que não houve diferenças estatísticas significativas entre as pontuações dos grupos GNT e GT para todos os estímulos (ALE 3.0 $[\mathrm{t}(60)=0,861$; p>0,05]; ALE 6.0 [t(60)=0,042; p>0,05]; ADG 3.0 [t(61)=-0,042; p>0,05] e ADG 6.0 $[\mathrm{t}(61)=0,237 ; \mathrm{p}>0,05])$.

Para o critério familiaridade as pontuações foram estatisticamente diferentes para todos os estímulos: ALE 3.0 [t(60)=5,224; p<0,01]; ALE 6.0 [t(60)=5,207; $\mathrm{p}<0,01] ;$ ADG $3.0 \quad[\mathrm{t}(56)=4,254 ; \mathrm{p}<0,01] \mathrm{e}$ ADG $6.0 \quad[\mathrm{t}(56)=4,708 ; \mathrm{p}<0,01]$. Os bailarinos julgaram os estímulos mais familiares do que os indivíduos não treinados em dança.

Para o critério complexidade houve diferença entre os grupos apenas para o estímulo ADG 3.0 [t(56)=2,020; $\mathrm{p}<0,05]$ : o Grupo Treinado pontuou este estímulo como mais complexo que o Grupo Não Treinado. Os demais estímulos ALE 3.0 [t(61)=1,047; $\mathrm{p}>0,05] ;$ ALE $6.0[\mathrm{t}(61)=1,389 ; \mathrm{p}>0,05]$ e ADG $6.0[\mathrm{t}(56)=0,123 ; \mathrm{p}>0,05]$ não apresentaram pontuações estatisticamente diferentes entre os grupos.

Para o critério movimento houve diferença apenas para o estímulo ADG 6.0 $[\mathrm{t}(56)=-2,611 ; \mathrm{p}<0,05]$ : os bailarinos julgaram este estímulo com menos movimento do que os não treinados. Os demais estímulos não apresentaram diferenças estatisticamente significativas entre as pontuações de cada grupo: ALE 3.0[t(60)=-0,195; p>0,05]; ALE $6.0[\mathrm{t}(60)=-1,770 ; \mathrm{p}>0,05] \mathrm{e}$ ADG $3.0[\mathrm{t}(56)=-0,631 ; \mathrm{p}>0,05]$.

Para o critério esforço físico houve diferença entre os valores médios dos grupos para os estímulos ALE $3.0[\mathrm{t}(60)=2,069 ; \mathrm{p}<0,05]$ e ADG $3.0[\mathrm{t}(56)=2,138$; $\mathrm{p}<0,05]$ os quais, para os bailarinos, foram julgados com mais esforço físico do que para os indivíduos não bailarinos. Os demais estímulos não apresentaram diferenças estatísticas significativas (ALE $6.0[\mathrm{t}(60)=1,183 ; \mathrm{p}>0,05]$ e ADG $6.0[\mathrm{t}(56)=0,70521$; $\mathrm{p}>0,05])$.

\section{Discussão}

As análises do Grupo Experimental Treinado (GT) mostraram duas possibilidades de explicação dos efeitos da interação música/imagem, da mesma forma como discutido para o grupo não treinado (GNT). Considerando as análises envolvendo 
as comparações entre estímulos, o efeito da imagem sobrepujou o efeito das músicas: a interação música/imagem entre os estímulos indicou efeito das imagens nas estimações temporais, não havendo efeito de música ou da interação música/imagem.

Por outro lado, considerando as análises comparando os estímulos com o tempo real de exposição dos mesmos foi também verificado um efeito das músicas sobre as imagens. Foi verificado o efeito da música em andamento mais rápido (Allegro) em relação ao tempo real de exposição de 36s, uma vez que os estímulos contendo este andamento foram estimados com duração semelhante ao tempo real de apresentação independentemente das imagens com mais e menos movimento. Inversamente, nos estímulos contendo andamento lento (Adágio) houve efeito das imagens: o estímulo ADG 3.0 foi subestimado, enquanto o estímulo ADG 6.0 foi estimado com duração semelhante ao tempo real de apresentação.

Estes resultados corroboram com os dados do grupo GNT e com estudos prévios (Nather \& Bueno, 2006a, b, 2008, 20011a) nos quais as imagens com maior representação de movimento são distintamente estimadas em relação àquelas com menores representações. Quando diferentes movimentos de balé foram apresentados com a música em andamento lento (Adágio), a intensidade de representação de movimento das imagens exerceu um efeito sobre a estimação subjetiva de tempo de pessoas treinadas em dança. Por outro lado, quando estes movimentos foram apresentados com a música em andamento rápido (Allegro) não foi verificado um efeito da representação de movimento das imagens. O efeito da música em andamento rápido (Allegro) sobre as imagens pode ser explicado através da congruência/incongruência dos passos representados com os andamentos musicais. De acordo com a técnica do Balé Clássico, o passo representado na imagem 6.0-pontos (Penché; Figura 4) é comumente executado em música de andamento lento (Bertoni, 1996). Dessa forma, o passo Penché e a música em andamento lento (Adágio) são congruentes. O passo representado na imagem 3.0-pontos (Tendu Devant; Figura 4) é executado tanto em músicas de andamento lento, como em músicas um pouco menos lentas (por exemplo, Moderato), mas dificilmente este passo é executado em Allegro, resultando em um estímulo incongruente.

O modelo de contraste proposto por Boltz (1989) propõe que a expectativa de previsibilidade de coerência de um evento no tempo fornece pistas que afetam a percepção temporal. Nesta perspectiva, a expectativa de um passo adequado para uma música ou vice-versa seria frustrada para o bailarino quando os passos de Tendu devant 
e Penché são apresentados com música em andamento Allegro. As distintas estimações observadas para os estímulos 3.0-pontos e 6.0-pontos, quando apresentados com a música em andamento lento (Adágio), podem ser mais coerentes que aquelas encontradas nas imagens com o andamento Allegro, porque há uma harmonia entre música/imagem. Portanto, os estímulos compostos de música/imagem congruentes (Adágio e os passos de Balé utilizados) foram estimados com durações temporais estatisticamente distintas; os incongruentes (Allegro e os passos de Balé) não foram estimados com durações temporais estatisticamente diferentes. Tais resultados não corroboram com os resultados de Meyer e Wuerger (2001). De acordo com os autores a sincronia entre o movimento sonoro e o visual faz com que o estímulo auditivo prevaleça sobre o visual. Mas é importante ressaltar que neste estudo foram utilizados estímulos sem conteúdo semântico (pontos e bips), diferentemente das imagens de corpos humanos em poses estáticas e músicas clássicas utilizadas no presente estudo.

A análise das escalas de diferencial semântico revelou que no Grupo Treinado (GT) os estímulos foram julgados diferentes em relação aos critérios de complexidade, esforço físico e movimento. Para os critérios de complexidade e esforço Físico, houve um efeito das imagens, por outro lado, em relação ao critério de movimento houve um efeito das imagens e das músicas. Estes resultados salientam o efeito das diferentes intensidades de movimento representado nas imagens, e ainda um efeito da música na intensidade de representação deste movimento. Pode-se inferir que o efeito das imagens nas estimações temporais entre os estímulos deve-se aos distintos passos de Balé representados nas imagens. E, por outro lado, o efeito das músicas nas estimações temporais dos estímulos, em relação ao tempo real de apresentação, deve-se aos distintos andamentos musicais apresentados.

Os relatos verbais dos participantes treinados, assim como os relatos dos participantes não treinados, revelaram que a música foi utilizada como principal estratégia para as estimações temporais. Quando perguntados sobre como estimaram o tempo, 79,60\% dos participantes disseram que se embasaram na música e 12,25\% disseram atentar para a imagem, outros 2,04\% disseram recordar de ambos os estímulos (musica imagem); 4,08\% relataram não fazer nada e 2,04\% disseram ter contado o tempo. Isto indica que tanto os participantes treinados (80\%) quanto os não treinados (50\%) escolheram a música como principal estratégia de estimação temporal: a informação visual da representação de movimento das imagens sobrepujou a informação auditiva dos andamentos musicais. 
Apesar de as análises estatísticas não terem revelado efeito entre os grupos GNT e GT nas comparações entre os estímulos, as análises das estimações dos estímulos com o tempo real de duração de 36 s revelaram que no grupo GNT o estímulo ALE 3.0 foi subestimado, mas no grupo GT o estímulo subestimado foi o ADG 3.0. Esta diferença mostra um efeito de aprendizagem na estimação subjetiva de tempo dos participantes, como aqueles já descritos por Nather, Bueno e Bigand (2009). Isto indica que há um efeito da interação música/imagem na estimação subjetiva de tempo e que o efeito é diferente entre indivíduos treinados e não treinados em dança.

Efeitos de aprendizagem abordados sobre diferentes aspectos da percepção de movimentos de balé (Calvo-Merino et al., 2005, 2006; Cross et al., 2006), visualização de imagens artísticas (Vogt et al., 2003) e de distintas abordagens metodológicas de tempo subjetivo (Cupchick, 1976; Cupchick e Gebotys, 1988) também revelam distintos efeitos relacionados ao treinamento. Uma explicação para o efeito do treinamento em Balé relaciona-se aos diferentes andamentos musicais que determinam diferentes categorias de exercícios de aula. Para Achcar (1986), Bambirra (1993) e Bertoni, (1996) a música clássica em andamento Allegro é típica de passos rápidos e precisos característicos deste tipo de andamento musical, por outro lado, músicas em andamento lento do tipo Adágio são típicas de um conjunto de passos suaves e delicados. É possível, que o bailarino, ao escutar músicas com estas distintas características resgate em seu repertório de conhecimento os passos cuja movimentação seja adequada a cada andamento musical. Mais que isso, ele saberá identificar, por exemplo, os passos intermediários para a execução de um Penché e implicitamente o esforço para se conseguir realizá-lo. Este conhecimento pode permitir ao bailarino identificar a velocidade da execução do movimento representado na imagem e relacioná-la ao andamento musical, alterando distintamente as suas estimações temporais em relação aos participantes não treinados.

Dados que comprovaram o efeito de aprendizagem podem ser exemplificados com as escalas de diferencial semântico. Os bailarinos (grupo GNT) julgaram as imagens mais familiares do que os indivíduos não treinados em dança. Além disso, para o grupo GNT o estímulo 3.0 (com ADG e ALE) foi considerado menos complexo que para o grupo GT. Em relação à representação de movimento os bailarinos julgaram o estímulo ADG 6.0 com menos movimento do que os indivíduos não treinados. Quanto ao esforço físico diferenças estatísticas significativas foram encontradas para os 
estímulos ALE 3.0 e ADG 3.0 os quais foram julgados com mais esforço pelos bailarinos. 


\section{Discussão Geral}

As apresentações conjuntas de trechos musicais e imagens estáticas com representação de movimento (interação música/imagem) afetaram a percepção subjetiva de tempo. Da mesma forma, um efeito de treinamento foi verificado nas estimações temporais dos participantes.

O efeito da interação música/imagem pôde ser observado sobre duas abordagens. A modalidade visual mostrou o efeito das imagens sobre os andamentos musicais, quando se comparou as estimações médias entre estímulos. A modalidade auditiva mostrou o efeito dos andamentos musicais sobre as imagens, quando se comparou a duração estimada dos estímulos com o tempo real de apresentação de 36s. na modalidade visual houve prevalência dos estímulos visuais sobre os estímulos acústicos nas estimações dos participantes de ambos os grupos (GNT e GT). Na modalidade auditiva os efeitos foram distintos entre os grupos: no grupo GNT, a música em Allegro exerceu um efeito no estímulo ALE 3.0 que foi subestimado e no estímulo ALE 6.0 que foi estimado com duração não estatisticamente diferente do tempo real. Contrariamente, no grupo GT o estímulo ADG 3.0 foi subestimado enquanto o estímulo ADG 6.0 foi estimado com duração não estatisticamente diferente do tempo real.

$\mathrm{Na}$ modalidade visual, tanto para o grupo GNT quanto para o GT, os valores das estimações temporais concordaram com os estudos prévios da literatura de tempo subjetivo e imagens com representação de movimento: quanto maior a representação de movimento em uma imagem estática maior será sua estimação temporal. (Nather \& Bueno, 2006b, 2008, 2011b; Nather et al., 2011). Na modalidade acústica, os distintos andamentos musicais causaram efeitos diferentes entre os grupos: por exemplo, os estímulos ALE 3.0 no grupo GNT (imagem com menos movimento e andamento rápido) e ADG 3.0 (imagem com menos movimento e andamento lento) no grupo GT foram subestimados, sendo os demais estímulos estimados com mesma duração que o tempo real (Tabela 5). O que explicaria esta diferença de efeito do andamento sobre o treinamento dos participantes?

O efeito dos andamentos musicais sobre o passo Tendu Devant (3.0-pontos) pode ser distinto para os indivíduos treinados e não treinados. Para não treinados, a música em Allegro por ser mais rápida pode sugerir mais movimento, contrastando com a visualização de uma posição de balé estática (incongruente). Para indivíduos treinados 
o passo representando na imagem 3.0-pontos é executável com músicas de andamento lento, mas não em andamento rápido (congruente). De acordo com Achcar (1986), Bambirra (1992) e Bertoni (1992), os passos representados nas imagens 3.0-pontos e 6.0-pontos (Tendu Devant e Penché, respectivamente) são executados em músicas de andamento lento, como o Adágio, portanto, para os bailarinos, é provável que a apresentação simultânea destas imagens com a música em Adágio seja percebida como congruente. Por outro lado, a apresentação destas imagens em conjunto com a música em andamento rápido, Allegro, seria percebida como incongruente pelos bailarinos. Isto explicaria as divergências encontradas entre as estimações dos estímulos ADG 3.0 e 6.0 e ALE 3.0 e 6.0.

Para Meyer e Wuerger (2001) a interação de estímulos acústicos e visuais pode resultar em um viés de resposta do estímulo acústico sobre o visual quando o primeiro é consistente ao segundo, ou seja, se o estímulo acústico é combinado ao estímulo visual em velocidade e direção é provável que o som influencie a resposta sobre o objeto visual. Portanto, pode-se inferir que a congruência entre o que se escuta e o que se vê em estímulos audiovisuais, podem resultar num domínio auditivo ou visual. Dessa forma, é provável que a congruência entre o passo representado na imagem e o andamento musical que é escutado simultaneamente possam resultar em distintos processamentos perceptivos. É importante salientar que além destes autores, trabalhos sobre interação de estímulos acústicos e visuais utilizaram como estímulos, por exemplo, flashes de luz, pontos e quadrados e sons de bips ou ruídos (Jack \& Thurlow, 1973; Radeau \& Bertelson, 1977, 1978; Welch \& Warren, 1980; Howard \& Templeton, 1996; Spence \& Driver, 1996, 1997; Stein et al., 1998; Mcdonald et al., 2000; Burr, Banks \& Morrone, 2009). Enquanto o presente estudo utilizou como estímulos visuais obras de arte, imagens de bailarinas em poses de balé, e como estímulos acústicos trechos de músicas clássicas, que possuem elaborados conteúdos semânticos.

Kosslyn (1981, 2005) e Kosslyn, Berhrmann e Jeannerods (2001) propõem o conceito denominado "Mental Imagery", ou imagem mental. Neste conceito a imagem mental visual seria "ver" na ausência do input sensorial imediato apropriado e a imagem mental auditiva seria "escutar" mesmo na ausência do input sensorial imediato apropriado para este sentido. Dessa forma, pode-se inferir que pessoas treinadas em dança, bailarinos, possuem em seu repertório a imagem mental do movimento assim como da música que acompanha este movimento, enquanto que pessoas não treinadas em dança não têm em seu repertório a mesma imagem mental. A existência de uma 
imagem mental relacionada ao estímulo observado no repertório do indivíduo provavelmente resulta em diferentes processamentos no momento da observação de imagens de corpos humanos em movimento, o que acarretaria nas diferentes estimações temporais dos estímulos nos diferentes andamentos musicais. Estudos focalizados nos efeitos de empatia e embodiment indicam que a resposta à observação estética consiste na ativação de mecanismos incorporados e na simulação de ações, emoções e sensação corporal (Freedberg \& Gallese, 2007). Para Nather et al. (2011) estes mecanismos também estão envolvidos na percepção subjetiva de tempo de imagens estáticas de bailarinas em diferentes posições.

As estimações temporais encontradas nos diferentes grupos podem ser discutidas em função dos resultados das escalas de diferencial semântico. Os bailarinos julgaram todos os estímulos mais familiares do que os participantes leigos em dança. Os indivíduos treinados julgaram o estímulo ADG 3.0 mais complexo e o estímulo ADG 6.0 com maior movimento do que os indivíduos não treinados. Para o critério esforço também foram encontradas diferenças: bailarinos julgaram os estímulos ALE 3.0 e ADG 3.0 com maior esforço físico do que os participantes não treinados.

Estas diferenças nos julgamentos das escalas de diferencial semântico podem ser explicadas pelas distintas formas de percepção do movimento entre indivíduos treinados e não treinados em dança verificada em trabalhos que relacionaram a percepção visual de movimento e treinamento em dança e capoeira. Calvo-Merino et al. $(2005,2006)$ verificaram que os indivíduos que possuíam conhecimento da dança observada (familiaridade) apresentaram grandes ativações bilaterais no córtex prémotor, nos sulcos intraparietais e em outras regiões cerebrais, o que não ocorria quando assistiam movimentos não familiares. Tal resultado indica que o processo de aprendizagem, que permite o conhecimento técnico e artístico da movimentação observada (técnica do balé clássico e da capoeira), pode influenciar diretamente na percepção de movimento do indivíduo. Cross et al. (2006) verificaram um aumento da atividade cerebral (parietal e pré-motora) correspondente à habilidade de executar uma ação aprendida.

Estes estudos indicam que, o conhecimento e a familiaridade da dança podem afetar diferentemente a ativação cerebral dos indivíduos no processamento da percepção visual de movimento de corpos humanos. É provável que estas diferenças possam contribuir para distintas estimações temporais entre pessoas treinadas e não treinadas em dança ao observarem imagens estáticas de corpos humanos em movimento. Para 
Brown, Martinez e Parsons (2005) existe uma rede interativa de áreas cerebrais que são ativadas durante movimentos rítmicos e padrões espaciais que são integrados ao dançar. De acordo com os autores a aprendizagem de movimentos complexos resulta em alterações funcionais e conectivas na reorganização e redistribuição de processos neurais. Portanto, é possível que as diferentes ativações cerebrais encontradas na percepção visual de movimento de pessoas treinadas e não treinadas em dança possam resultar também em diferenças nas estimações temporais de participantes em estudos de tempo subjetivo.

Nos relatos verbais sobre como estimaram o tempo, tanto os indivíduos treinados em dança quanto aqueles não treinados relataram prestar mais atenção a música do que à imagem como marcador temporal. Isto indica que em ambos os grupos a música foi escolhida com estratégia para a realização das estimações temporais. Estes resultados corroboram com o estudo de Burr, Banks e Morrone (2009). Os autores verificaram que a audição tende a dominar a visão em tarefas que demandam um processamento temporal, e denominaram este efeito de ventriloquismo temporal, entretanto este domínio não é total e pode variar de indivíduo para indivíduo. A parcialidade deste domínio também foi encontrada no presente estudo, pois apesar de haver uma influência do andamento musical o efeito da representação de movimento também foi verificado, mesmo sob influência musical.

De acordo com Cupchick e Getbotys (1988) e Nather, Bueno e Bigand (2009) pessoas treinadas em artes tendem apresentar estimações temporais distintas de pessoas não treinadas. Provavelmente, o conhecimento prévio do que se observa faz com que o indivíduo demande mais ou menos esforço perceptivo/cognitivo, gerando distintos estados internos nos indivíduos. Assim, as esculturas de Degas com maiores representações de movimento como, por exemplo, os passos de Arabesques (Penché; 6.0-pontos) tendem a ser superestimados. De acordo com Nather e Bueno (2006b, 2008, 2011b), imagens com maiores representações de movimento são mais complexas e requerem maior processamento e espaço de armazenamento na memória (Ornstein, 1969) e devem induzir nos indivíduos maior atenção dirigida (Thomas \& Weaver, 1975; Underwood \& Swain,1973), resultando em maiores estimações temporais. Para indivíduos não treinados, imagens estáticas de corpos humanos em diferentes passos de balé fornecem pistas de qual teria sido o começo, o meio e o fim do movimento criando uma expectativa do tempo necessário para executá-lo (Boltz, 1989). 
Provavelmente, a ativação interna (arousal) de indivíduos treinados e não treinados em dança seja diferente na estimação temporal de imagens de bailarinas e de músicas clássicas. De acordo com o modelo do relógio interno (Treisman, 1963; Gibbon, Chuch e Mech, 1984), pode-se inferir que estes diferentes níveis de arousal entre bailarinos e não bailarinos podem resultar em diferenças no funcionamento do marcapasso temporal dos indivíduos. Isto poderia explicar as diferenças encontradas entre os grupos GNT e GT.

Os resultados desta pesquisa confirmaram que existem diferenças nas estimações temporais entre indivíduos treinados e não treinados em dança. O presente estudo revelou que a interação música/imagem também acarreta diferenças nas estimações temporais. Foi verificado um efeito do estímulo acústico sobre o visual nas estimações temporais dos estímulos em relação ao tempo real de duração (modalidade auditiva), e um efeito das imagens nas estimações temporais entre os estímulos (modalidade visual). Andamentos lentos tendem a influenciar mais as estimações temporais de indivíduos treinados enquanto que andamentos rápidos exercem maior influência nas estimações de indivíduos não treinados.

Estudos subseqüentes poderão abordar a interação música/imagem na apreciação estética para que as propriedades colativas, inerentes às obras de arte, possam ser mais bem discutidas em pesquisas de tempo subjetivo que utilizam obras de arte audiovisuais. O efeito da interação música/imagem na estimação subjetiva de tempo poderá ainda, ser estudado sob diferentes paradigmas (retrospectivo e prospectivo) para que se possa verificar se as diferenças encontradas em estímulos unimodais também serão verificadas em estímulos audiovisuais, revelando qual será a percepção sobressalente ou se haverá sobreposição de alguma das modalidades perceptuais dos estímulos nos diferentes paradigmas. 


\section{Referências Bibliográficas ${ }^{19}$}

ACHCAR, D. Ballet: arte, técnica, interpretação. Cia. Brasileira de Artes Gráficas: Rio de Janeiro, 1986.

ALI, A. E. Reproducing the passage of time: effects of stimulus complexity, quantity, and cognitive interference. 2008, 75f. Dissertação de Mestrado: Universiteit van Amsterdan, Holanda, 2008.

ANDERSEN, T. S.; TIIPPANA, K.; SAMS, M. Factors influencing audiovisual fission and fusion illusions. Cognitive Brain Research, 21(3), 301-308, 2004.

ARGAN, G. C. Arte Moderna: do iluminismo aos movimentos contemporâneos. Companhia das Letras: São Paulo, 1995.

BAMBIRRA, W. Dançar e sonhar: a didática do ballet infantil. Belo Horizonte: Sprint, 1993.

BERGER, T. D.; MARTELLI, M.; PELLI, D. G. Flicker flutter: is an illusory event as good as the real thing? Journal Vision, 3(6), 406-412, 2003.

BERLYNE, D. E. The new experimental aesthetics. In: BERLYNE, D. E. (Org.). Studies in the new experimental aesthetics. Toronto: University of Toronto, 1-25, 1974.

BERTONI, I. G. O ballet e seu contexto histórico: programação didática. Tanz do Brasil: São Paulo, 1992.

BLOCK, R. A. Experiencing and remembering time: affordances, context, and cognition. In: BLOCK, R. A. (Org.). Time, mind and behavior. Heidelberg: Springer Verlag, 169-178, 1985.

BLOCK, R. A. Cognitive models of psychological time. Hillsdale: New Jersey, 1990.

BLOCK, R. A.; ZAKAY, D. Prospective and retrospective duration judgments: a metaanalytic review. Psychonomic Bulletin \& Review, 4(2), 184-197, 2004.

BOLTZ, M. Time judgments of musical endings: effects of expectancies on the "filled interval effect”. Perception \& Psychophysics, 46(5), 409-418, 1989.

BRADDICK, O. The many faces of motion perception. In: BRADDICK, O. (Org.). The artful eye. Oxford: Oxford University Press, 205-231, 1995.

BROWN, S. W. Time perception and attention: The effects of prospective versus retrospective paradigms and task demands on perceived duration. Perception \& Psychophysics, 38, 115-124, 1985.

\footnotetext{
${ }^{19}$ De acordo com a Associação Brasileira de Normas Técnicas. NBR 6023.
} 
BROWN, S. W. Time, change, and motion: the effects of stimulus movement on temporal perception. Perception \& Psychophysics, 1, 105-116, 1997.

BROWN, S.; MARTINEZ, M. J.; PARSONS, L. M. The Neural Basis of Human Dance. Cerebral Cortex Advance, 17, 1-11, 2005.

BUENO, J. L. O.; FIRMINO, E. A.; ENGELMANN, A. Influence of generalized complexity of a musical event on subjective time stimulation. Perceptual and Motor Skills, 94, 541-547, 2002.

BUENO, J. L. O.; RAMOS, D. Musical mode influence and estimation of time. Perceptual and Motor Skills, 105, 1087-1092, 2007.

BUETTI, D.; BAHRAMI, B.; WALSH, V. Sensory and association cortex in time perception. Journal of Cognitive Neuroscience, 20(6) 1054-1062, 2008.

BULKING, D. A.; GROH, J. G. Seeing sounds: visual and auditory interactions in the brain. Current Opinion in Neurobiology, 16, 415-419, 2006.

BURR, D.; BANKS, M. S.; MARRONE, M. C. Auditory dominance over vision in the perception of interval duration. Experimental Brain Research, 198, 49-57, 2009.

CALVO-MERINO, B.; GLASER, D. E.; GRÉZES, R. E.; PASSINGHAM, R. E.; HAGGARD, P. Action observation and acquired motor skills: an fMRI study with expert dancers. Cerebral Córtex, 15, 1243-1249, 2005.

CALVO-MERINO, B.; GLASER, D. E.; GRÉZES, R. E.; PASSINGHAM, R. E.; HAGGARD, P. Seeing or doing? Influence of visual and motor familiarity in action observation. Current Biology, 16, 1905-1910, 2006.

CAMINADA, Eliana. História da Dança: evolução cultural. Sprint: Rio de janeiro, 1999.

COCENAS, R. Percepção Subjetiva de tempo durante uma apreciação erudite ocidental: uma análise multimodal. 2009. 80f. Dissertação de Mestrado - Faculdade de Filosofia Ciências e Letras de Ribeirão Preto, Universidade de São Paulo, Ribeirão Preto, 2009.

COCENAS, R.; BUENO, J. L. O.; BIGAND, E.; MOLIN, P. Escala multidimensional aplicada aos estudos de apreciação musical. Paidéia, 19(43), 153-158, 2009.

CROSS, E. S.; HAMILTON, A. F.; GRAFTON, S. T. Building a motor simulation de novo: observation of dance by dancers. Neuroimage, 31, 1257-1267, 2006.

CUPCHICK, G. C. Perspective théorique et empirique sur peintures impressioniste. Bulletin de Psychologie, 36, 720-729, 1976.

CUPCHICK, G. C.; GEBOTYS, R. The experience of time, pleasure, and interest during aesthetic episodes. Empirical Studies of the Arts, 6, 1-12, 1988. 
CUTTING, J. E. Representing motion in a static image: constraints and parallels in art, science, and popular culture. Perception, 31(10), 165-1193, 2002.

DROIT-VOLET, S.; TOURRENT, S.; WEARDEN, J. Perception of the duration of auditory and visual stimuli in children and adults. The quarterly journal of experiemntal psychology, 36 (5), 797-818, 2004.

DUPPONT, P.; ORBAN, G. A.; VERBRUGGEN, A.; MORTELMANS, L. Many areas in the human brain respond to visual motion. Journal of Neurophysiology, 72, 14201424, 1994.

ENGELMAN, D. M.; PARYADATH, V. Is subjective duration a signature of coding efficiency? Biological Sciences, 364, 1841-1851, 2009.

FIRMINO, E. A. Modulação tonal e tempo subjetivo. 2003, 135f. Dissertação de Mestrado - Instituto de Biociências, Universidade de São Paulo, São Paulo, 2003.

FIRMINO, E. A.; BUENO, J. L. O. Tonal modulation and subjective time. Journal of New Musical Research, 37, 275-297, 2008.

FIRMINO, E. A.; BUENO, J. L. O.; BIGAND, E. Travelling through pitch space speeds up musical time. Music Perception, 26, 205-209, 2009.

FOURTIN, C.; ROUSSEAU, R. Time estimation as an index of processing demand in memory search. Perception \& Psychophysics, 42 (4), 377-382, 1987.

FRAISSE, P. Psychologie du temps. PUF: Paris, 1963.

FRAISSE, P. Perception and estimation of time. Annual Review of Psychology, 35, 136, 1984.

FREEDBERG, D.; GALLESE, V. Motion, emotion e empathy in esthetic experience. Trends in cognitive sciences, 11(5), 197-203, 2007.

FREYD, J. J. The mental representation of movement when static stimuli are viewed. Perception and Psychophysics, 33(6), 575-581, 1983.

GIBBON, J.; CHUCH, R. M.; MECH, A. Sources of variance in an information processing theory of timing. In: ROITBLA, H. L.; BEVER, T. G.; TERRACE, H. S. (Eds.), Animal cognition, 465-488. Hillsdale, NJ: Erlbaum, 1984.

GRAF, P.; GRONDIN, S. Time Perception in Time-Based Prospective Memory. In: GLICKSON, J.; MYSLOBODSKY, M. S. (Eds.), Timing the future: the case for a time-based prospective memory, 1-24. River Edge, NJ: World Scientific Publishing, 2006.

GRONDIN, S. Timing and time perception: a review of recent behavioral and neuroscience findings and theoretical directions. Attention, Perception, \& Psychophysics, 72(3), 561-582, 2010. 
GROWE, B. Degas. Taschen: Alemanha, 2001.

HOWARD, I. P.; TEMPLETON, W. B. Human spatial orientation. Wiley: London, 1966.

JACK, C. E.; THURLOW, W. R. Effects of degree of visual association and angle of displacement on the "ventriloquism" effect. Perceptual and Motor Skills, 37(3), 967979, 1973.

JONES, M. R.; BOLTZ, M. Dynamic attending and responses to time. Psychological Review, 96, 459-491, 1989.

KLAPPROTH, F. The effect of modality on retrieval of subjective duration from longterm memory. Behavior Process, 59(1), 37-46, 2002.

KOSSLYN, S. M. The Medium and the message in mental-imagery: a theory. Psychological Review, 88(1), 46-66, 1981.

KOSSLYN, S. M. Mental images and the brain. Cognitive Neuropsychology, 22(3-4), 333-347, 2005.

KOSSLYN, S. M.; BERHRMANN, M.; JEANNERODS, M. The cognitive neuroscience of mental-imagery. Neuropsychologia, 11, 1335-1344, 1995.

KOURTZI, Z.; KANWISHER, N. Activation in human MT/MST by static images with implied motion. Journal of Cognitive Neuroscience, 12, 48-55, 2000.

KOURTZI, Z.; SHIFFRAR, M. Dynamic representations of human body movement. Perception, 28, 49-62, 1999.

KREKELBERG, B. Sound and vision. Trends in Cognitive Sciences, 7, 277-279, 2003.

LACERDA, O. Compendio de teoria elementar da música. Ricordi: São Paulo, 1967.

LELIS, C. M. C. Influência de audições musicais com variação de composição sobre estimação objetiva de tempo. 2002, 38f. Dissertação de Mestrado - Faculdade de Filosofia Ciências e Letras, Universidade de São Paulo, Ribeirão Preto, 2002.

MARQUES, L. Degas e o movimento. São Paulo: Marca D’Àgua, 1999.

MENDES, M. G. A dança. Ática: São Paulo, 2001.

MEYER, G. F.; WUERGER, S. M. Cross-modal integration of auditory and visual motion signals. NeuroReport, 12(11), 2557-2560, 2001.

MCDONALD, J. J.; TEDER-SA ÈLEJA ÈRVI, W. A.; HILLYARD, S. A. Involuntary orienting to sound improves visual perception. Nature, 407, 906-908, 2000. 
NATHER, F. C. Percepção de movimento e tempo subjetivo nas artes visuais. 2006. 169f. Tese de Doutorado - Faculdade de Filosofia Ciências e Letras de Ribeirão Preto, Universidade de São Paulo, Ribeirão Preto, 2006.

NATHER, F.; BUENO, J. L. O. Tempo subjetivo e percepção de movimento em obras de arte. Estudos de Psicologia, 11(3), 265-274, 2006 .

NATHER, F.C.; BUENO, J. L. O. Efeito de imagens estáticas com diferentes representações de movimento sobre a percepção subjetiva de tempo. Psicologia: Reflexão \& Crítica, 19, 217-224, 2006 b.

NATHER, F. C.; BUENO, J. L. O. Movement ranking scale of human body static images for subjective timing estimation. In: 24th Annual Meeting of the International Society for Psychophysics - Fechnerday 2008. Toronto: Canadá, 185-190, 2008.

NATHER, F. C.; BUENO, J. L. O. Timing perception in paintings and sculptures of Edgar Degas. Kronoscope, (no prelo), 2011a.

NATHER, F. C.; BUENO, J. L. O. Static images with different intensities of human body movement affect subjective time perception. Perceptual and Motor Skills, (no prelo), $2011 \mathrm{~b}$.

NATHER, F. C.; BUENO, J. L. O.; BIGAND, E. Time estimation and eye-tracking movement in human body static images. In the $\mathbf{2 5}^{\text {th }}$ Proceedings of Annual Meeting of the Society for Psychophsics. Galway: Ireland, 399-404, 2009.

NATHER, F. C.; GIANETTI, S.; BUENO, J. L. O. Percepção de movimento em obras de arte abstrata e seu efeito na estimação subjetiva de tempo. In: $18^{\circ}$ Simpósio Internacional de Iniciação Científica da USP. Ribeirão Preto, São Paulo, 2010.

NATHER, F. C.; BUENO, J. L. O.; BIGAND, E.; DROIT-VOLET, S. Time changes with the embodying the another's body posture. Plos One, 6(5), e19818, 2011.

NORTH, A. C.; HARGREAVES, D. J.; HEATH, S. J. Musical tempo and time perception in a gymnasium. Psychology of Music, 26, 78-88, 1998.

ORNSTEIN, R. E. On the experience of time. Harmondsworth: Penguin, 1969.

PAVLOV, A. Dicionário de ballet. Editorial Nórdica: Rio de Janeiro, 2000.

PENNEY, T. B.; GIBBON, J. Differential effects of auditory and visual signals on clock speed and temporal memory. Human Perception and Performance, 26(6), 1770-1787, 2000.

RADEAU, M.; BERTELSON, P. Adaptation to auditory-visual discordance and Ventriloquism in semi realistic situations. Perception \& Psychophysics, 22, 137-146, 1977.

RADEAU, M.; BERTELSON, P. Cognitive factors and adaptation to auditory-visual discordance. Perception \& Psycophysics, 23, 341-343, 1978. 
RAMOS, D. Fatores emocionais durante uma escuta musical afetam a percepção temporal de músicos e não músicos? 2007, 268p. Tese de Doutorado - Faculdade de Filosofia Ciências e Letras, Universidade de São Paulo, Ribeirão Preto, 2007.

RECANZONE, G. H. Rapidly induced auditory plasticity: the ventriloquism aftereffect. National Academy of Science, 5, 869-875, 1998.

RECANZONE, G. H. Auditory influences on visual temporal rate perception. Journal of Neurophysiology, 89,1078-1093, 2003.

RECANZONE, G. H. Interactions of auditory and visual stimuli in space and time. Hearing Research, 258, 89-99, 2009.

RIZZOLATTI, G.; CRAIGHERO, L. The mirror neuron system. Annual Review of Neuroscience, 27(30), 169- 192, 2004.

SHIFFAR, M.; FREYD, J. J. Timing and apparent motion path choice with human body photographs. American Psychological Society, 4(6), 379-374, 1993.

SPENCE, C.; DRIVER, 1. Audiovisual links in endogenous covert spatial attention. Journal of Experimental Psychology: Human Perception \& Performance, 22, 10051030, 1996.

SPENCE, C.; DRIVER, 1. Audiovisual links in exogenous covert spatial orienting. Perception \& Psychophysics, 59, 1-22, 1997.

SHAMS, L.; KAMITANI,Y.; SHIMOJO, S. Illusions: what you see is what you hear. Nature, 408-788, 2000.

STUDIO DE DANÇA LUCIANA JUNQUEIRA. Apostila de Formação Técnica em Dança. Ribeirão Preto, São Paulo, 2001.

STRICKLAND, C. Arte comentada: da pré-história ao pós-moderno. Ediouro: Rio de Janeiro, 2004.

THOMAS, E. A. C.; WEAVER, W. B. Cognitive processing and time perception. Perception \& Psychophysics, 17, 363-367, 1975.

TOOTELL, R. B. H.; REPPAS, J. B.; DALE, A. M.; LOOK, R. B. Visual motion after affect in human cortical area MT revealed by functional magnetic resonance imaging. Nature, 11, 139-141, 1995.

TRIESMAN, M. Temporal discrimination and the indifference interval: Implications for a model of the "internal clock". Psychological Monographs, 77(13), 1-31, 1963.

UNDERWOOD, G.; SWAIN, R. Selectivity of attention and the perception of duration. Perception, 2, 101-105, 1973. 
URGESI, C.; MORO, V.; CANDIDI, M.; AGLIOTI, S. M. Mapping implied body actions in the human motor system. The Journal of Neuroscience, 26(30), 7942- 7949, 2006.

VERFAILLIE, K.; DAEMS, A. Representing and anticipating human actions in vision. Visual Cognition, 9, 217-232, 2002.

VOGT, S.; TAYLOR, P.; HOPKINS, B. Visuomotor priming by pictures of hand postures: perspective matters. Neuropsychologia, 41, 941-951, 2003.

WATANABE, K.; SHIMOJO, S. Postcoincidence trajectory duration affects motion event perception. Perception \& Psychophysics, 63, 16-28, 2001.

WELCH, R. B.; WARREN, D. H. Immediate perceptual response to intersensory discrepancy. Psychological Bulletin, 88, 638-667, 1980.

ZAKAY, D. The evasive art of subjective time measurement: some methodological dilemas. In: BLOCK, R. A. (Org.), Cognitive models of psychological time, 59-84. Hillsdale, NJ: Erlbaum, 1990.

ZAKAY, D.; BLOCK, R. A. Temporal cognition. Current Directions in Psychological Science, 6, 12-16, 1997.

ZAKAY, D.; BLOCK, R. A. Prospective and retrospective duration judgments: an executive-control perspective. Acta Neurobiologiae Experimentalis, 64, 319-328, 2004. 


\section{Apêndices}

Apêndice I: Relação entre andamento musical e passos de balé.

A estrutura geral de um CD específico para uma aula de balé po apresentada da seguinte forma:

\section{Música/ Exercício}

1. Barra

Aquecimento

Plié

Tendu

Jettè

Rond de Jambe

Fondu

Frappé

Petit Battement

Rond em L'àir

Adágio

Grand Battement

Alongamento

\section{Andamento musical}

Lento

Moderado

Moderado e rápido

Rápido

Lento e moderado

Lento e moderado

Rápido

Rápido

Lento ou Moderado

Lento

Moderado

Lento

Moderado

Moderado/Rápido

Lento

Rápido

Rápido

Moderado

Rápido

Lento 
Apêndice II: Procedimentos para a seleção dos estímulos utilizados nos experimentos.

\section{Seleção Estímulos Visuais}

Utilização dos estímulos 3.0-point e 6.0-point da Body Moviment Ranking Scale (Nather e Bueno; 2008). Os estímulos foram testados no novo programa Wave Surfer 2010 elaborado para o estudo, que permite a apresentação de imagens e músicas ao mesmo tempo.

\section{Seleção e elaboração Estímulos Acústicos}

Etapa 1 (Seleção de músicas do tipo Allegro):

Foram selecionadas Músicas Clássicas de andamento rápido (Allegro) de cd’s específicos para aulas de balé, nestes cd’s o instrumento principal é o piano.

A escolha destas obras seguiu os seguintes critérios: 1- Ser um Allegro; 2- A primeira frase musical (primeira parte da composição) deveria ter 36 segundos para que a música pudesse ser utilizada no formato original;

As obras selecionadas na primeira etapa foram: Gallops/Kicking; Jolly Giants e Polka do pianista Joe Cross;

Etapa 2 (Alteração do trecho Allegro para Adágio):

Para a alteração do estímulo original em Allegro para um andamento mais lento (Adágio) foi utilizado o programa Audacity Setup 1.0. Das músicas préselecionadas apenas a música Jolly Giants se ajustou melhor a alteração do seu andamento. Entretanto, após várias tentativas de ajuste do estímulo verificou-se que ao alterar o andamento do trecho musical, de rápido para lento, ocorria uma distorção no tom da música alterada. Tal alteração fez com que as músicas adquirissem características não comparáveis em situação experimental. No passo seguinte optou-se por selecionar trechos em andamento lento, objetivando eliminar as distorções obtidas no tom musical.

Etapa 3 (Seleção de músicas do tipo Adágio):

Foram utilizados os mesmos critérios adotados na Etapa 1 (alegro). As seguintes obras foram selecionadas: Idyll de C. W. Gluck; Spring de F. W. Bach e Tea at cottage de Rowy. 
Etapa 4 (Alteração do trecho Adágio para Allegro):

Após as alterações com o programa Audacity Setup 1.0 verificou-se que a distorção da música diminuiu consideravelmente, ou seja, quando o estímulo original era um adágio sua transformação para um andamento rápido resultava em menores distorções. Entretanto, mesmo que pequenas estas distorções poderiam afetar a qualidade da música. Dessa forma, verificou-se que o programa Audacity Setup 1.0 não permitiu a elaboração de estímulos adequados ao projeto.

Etapa 5 (Seleção de músicas do tipo Allegro):

A colaboração do Prof. Dr. Érico Firmino, músico e compositor, propiciou a definição do trecho musical alterado que será utilizado no estudo. Por sugestão do músico, o estímulo escolhido foi Idyll de C. W. Gluck (1714 - 1797), pois a análise desta obra revelou que sua primeira frase musical era de 36 segundos. Além disso, esta música estava disponível em formato MIDI (partitura virtual manipulável), o que permitiria uma melhor manipulação dos elementos musicais. Foram utilizados os programas Encore 4.5.3 e Sound Forge 7.0.2 para a transformação da música original Idyll de Gluck com andamento tipo Adágio (lento) correspondente a $26 \mathrm{bpm}$ (batidas por minuto) para a versão Allegro (rápido) do trecho escolhido, com andamento em 52 bpm, ou seja, o dobro do andamento do estímulo original. 
Anexos

Anexo I: Questionário Experimental

\section{QUESTIONÁRIO DE COLETA}

Participante:

Data:

Início: Término:

\section{Dados pessoais}

a. Data de nascimento:

b. Sexo: ( ) masculino ( ) feminino

c. Nacionalidade:

d. Cidade onde residiu durante a maior parte da vida:

e. Formação Acadêmica:

f. Ocupação Atual:

g. Como você considera seu estado físico e emocional hoje:

( ) Bom ( ) Razoável ( ) Mal

\section{Dados relacionados à prática de dança do participante}

a. Qual a sua formação em Dança ?

b. Em média, quantas horas de balé você pratica por dia?

c. Você estuda ou estudou música ? ( ) Não （ ) Sim

d. Caso a resposta seja positiva, qual instrumento musical você estuda ou estudou ?

e. Há quanto tempo? 


\section{Dados relacionados ao Experimento}

a. Você contou o tempo, de alguma maneira?

b. Você conhecia as músicas que escutou?

c. As músicas que você escutou o fizeram lembrar de alguma coisa ? Caso a resposta seja positiva, do que você se lembrou durante a escuta?

d. Qual a sua motivação ou interesse para participar deste estudo ?

e. Em sua opinião, qual é o objetivo deste estudo? Você formulou alguma hipótese durante o experimento?

f. Você considera a sua audição normal ou sente que tem alguma dificuldade?

g. Tem algum comentário ou sugestão a fazer em relação ao experimento que você participou?

\section{O B R I G A D A!}


Anexo II: Modelo das Escalas de Diferencial Semântico

Esta apresentação de Imagem/Música é pouco ou muito agradável?

\begin{tabular}{|l|l|l|l|l|l|l|}
\hline 1 & 2 & 3 & 4 & 5 & 6 & 7 \\
\hline
\end{tabular}

A bailarina representada nesta escultura apresenta pouco ou muito movimento?

\begin{tabular}{|l|l|l|l|l|l|l|}
\hline 1 & 2 & 3 & 4 & 5 & 6 & 7 \\
\hline
\end{tabular}$+$

O movimento representado nesta escultura é pouco ou muito familiar?

\begin{tabular}{|l|l|l|l|l|l|l|}
\hline 1 & 2 & 3 & 4 & 5 & 6 & 7 \\
\hline
\end{tabular}

A posição corporal representada nesta escultura exige pouco ou muito esforço físico?

\begin{tabular}{|l|l|l|l|l|l|l|}
\hline 1 & 2 & 3 & 4 & 5 & 6 & 7 \\
\hline
\end{tabular}$+$

A execução desta posição corporal é pouco ou muito complexa?

\begin{tabular}{|l|l|l|l|l|l|l|}
\hline 1 & 2 & 3 & 4 & 5 & 6 & 7 \\
\hline
\end{tabular}$+$

A velocidade desta música é pouco ou muito veloz?

\begin{tabular}{|l|l|l|l|l|l|l|}
\hline 1 & 2 & 3 & 4 & 5 & 6 & 7 \\
\hline
\end{tabular}$+$


Anexo III: Imagens utilizadas e resultados obtidos na pesquisa de Kourtzi e Kanwisher (2000).

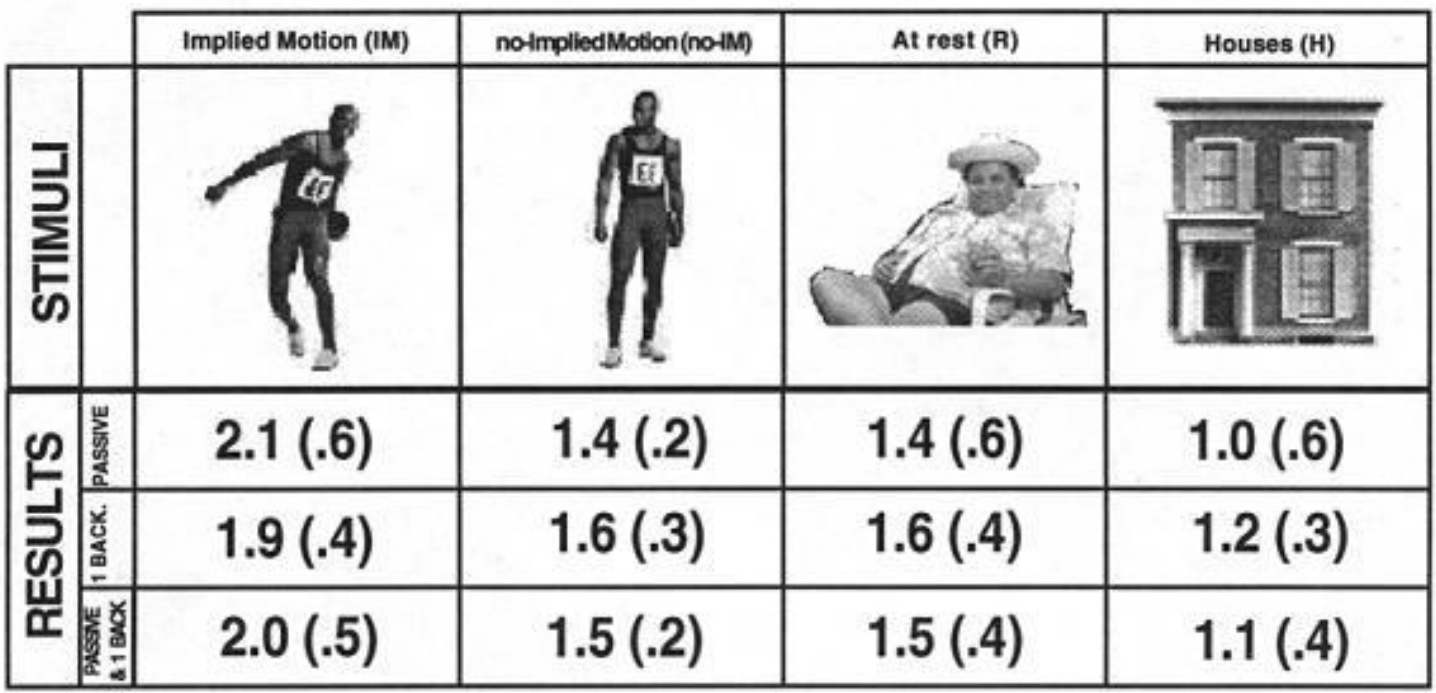

